\title{
Sequence stratigraphic interpretation of a Pennsylvanian (Upper Carboniferous) coal from the central Appalachian Basin, USA
}

\author{
RHODRI M. JERRETT *, STEPHEN S. FLINT *, ROY C. DAVIES $\dagger$ and DAVID M. HODGSON * \\ *Stratigraphy Group, School of Environmental Sciences, University of Liverpool, 4 Brownlow Street, \\ Liverpool L69 3GP, UK (E-mail: rhodri.jerrett@liv.ac.uk) \\ $\dagger$ †.ON Ruhrgas Norge AS, Løkkeveien 107, 4007 Stavanger, Norway
}

\begin{abstract}
Peat mires retain a sensitive record of water-table (base-level) fluctuations throughout their accumulation. On this basis, coals provide one of the best opportunities to interpret high-resolution base-level change in ancient nonmarine deposits. The petrographic composition of 275 samples collected from 11 localities along a $100 \mathrm{~km}$ south-west to north-east transect across the regionally extensive ( $>37000 \mathrm{~km}^{2}$ ) Pennsylvanian (Upper Carboniferous) Fire Clay coal of the Central Appalachian Basin, USA was analysed to determine its internal stratigraphy. The coal is positioned within the late lowstand/early transgressive systems tract of a fourth-order depositional sequence. The results of the petrographic analyses reveal a cyclicity in the composition of the Fire Clay coal, which defines six units that are correlated over more than $100 \mathrm{~km}$. Each coal cycle is characterized by a gradual upward transition from vitrinitedominated to inertinite-dominated coal, which represents a 'drying-up' succession. Increased concentrations of resistant peat components at the top of the drying-up successions indicate reduced peat accumulation rates associated with slowing rate of water-table rise, and may represent a residue of peat remaining from a phase of exposure and erosion resulting from a falling water table. These drying-up successions are bound by surfaces that display an abrupt coal facies shift from inertinite-rich to vitrinite-rich coal, representing a rapid water-table rise. Each cycle represents markedly different mire conditions with different aerial distributions, which supports the notion of temporal disconnection between each unit of coal, and suggests that considerable time may be 'locked-up' in unit bounding exposure surfaces. Recognition that the rate of peat accumulation in a mire may vary considerably through time, has important implications for studies which assume that peat and coal successions provide continuous and time-invariant records of baselevel fluctuations or palaeoecological change.
\end{abstract}

Keywords Appalachian Basin, coal, Pennsylvanian, petrography, sequence stratigraphy.

\section{INTRODUCTION}

In peat-forming environments, the mire watertable elevation is approximately equal to base level, as it defines the level above which peat is exposed to oxidation and degradation (Clymo, 1983; Bohacs \& Suter, 1997). In paralic settings, the height of the mire water table is a function of relative sea-level and effective precipitation
(Clymo, 1987; Moore, 1989; Kosters \& Suter, 1993; Tornqvist, 1993; Winston, 1994; Banerjee et al., 1996), whilst accommodation is controlled by the height of the mire water table, basin subsidence and sediment compaction (Bohacs \& Suter, 1997). In order for peat to be preserved, the accommodation rate must approximately balance the rate of peat production (Cross, 1988; Diessel, 1992; Bohacs \& Suter, 1997). If the long-term 
accommodation rate outpaces the peat production rate, the mire is inundated by marine, lacustrine or terrestrial sediments. If the peat production rate exceeds the accommodation rate, the mire is exposed, oxidized and reworked. High-frequency variations in the rates of accommodation and peat production within the comparatively narrow 'peat window' result in changes in the hydrology, botany and, therefore, composition of the accumulating peat (Fig. 1). As the maximum rate of peat production in a given latitudinal zone is relatively constant during the accumulation period of a peat (Diessel et al., 2000), compositional changes within the deposit are controlled primarily by the accommodation rate.

On this basis, a number of studies (Banerjee et al., 1996; Petersen \& Andsbjerg, 1996; Diessel, 1998; Petersen et al., 1998; Diessel et al., 2000; Holz et al., 2002; Wadsworth et al., 2002, 2003; Davies et al., 2005, 2006; Silva et al., 2008) have explored the high-frequency accommodation changes recorded by Palaeozoic, Mesozoic and Cenozoic coal seams, by recognizing changes in the internal compositional characteristics of the coals. A key advance demonstrated by these studies is that peat can accumulate during increasing or decreasing rates of accommodation, and can span multiple accommodation cycles (Bohacs \& Suter, 1997; Diessel et al., 2000; Wadsworth et al., 2002). Diessel et al. (2000) and Wadsworth et al. (2002) interpreted several key surfaces of terrestrial sequence stratigraphic significance that represent the equivalent of marine flooding surfaces and sequence boundaries, developed in coal-bearing strata. This approach has been extended in this study (Fig. 1). In a 'drying-up' succession, the initiation of peat accumulation above marine, lagoonal or lacustrine strata represents a terrestrialization surface (TeS), which is non-hiatal because it indicates a transition from clastic sedimentation to peat accumulation in response to shallowing (Diessel et al., 2000). A continued decrease in the accommodation rate will eventually result in zero accommodation, terminating the accumulation of peat (Moore, 1995) or terrigenous clastic sediments and producing a hiatal or erosional subaerial exposure surface (ES). In a 'wetting-up' succession, the initiation of peat accumulation above subaerial, terrigenous strata represents a paludification surface $(\mathrm{PaS})$, which may be hiatal or non-hiatal, depending on the rate of clastic

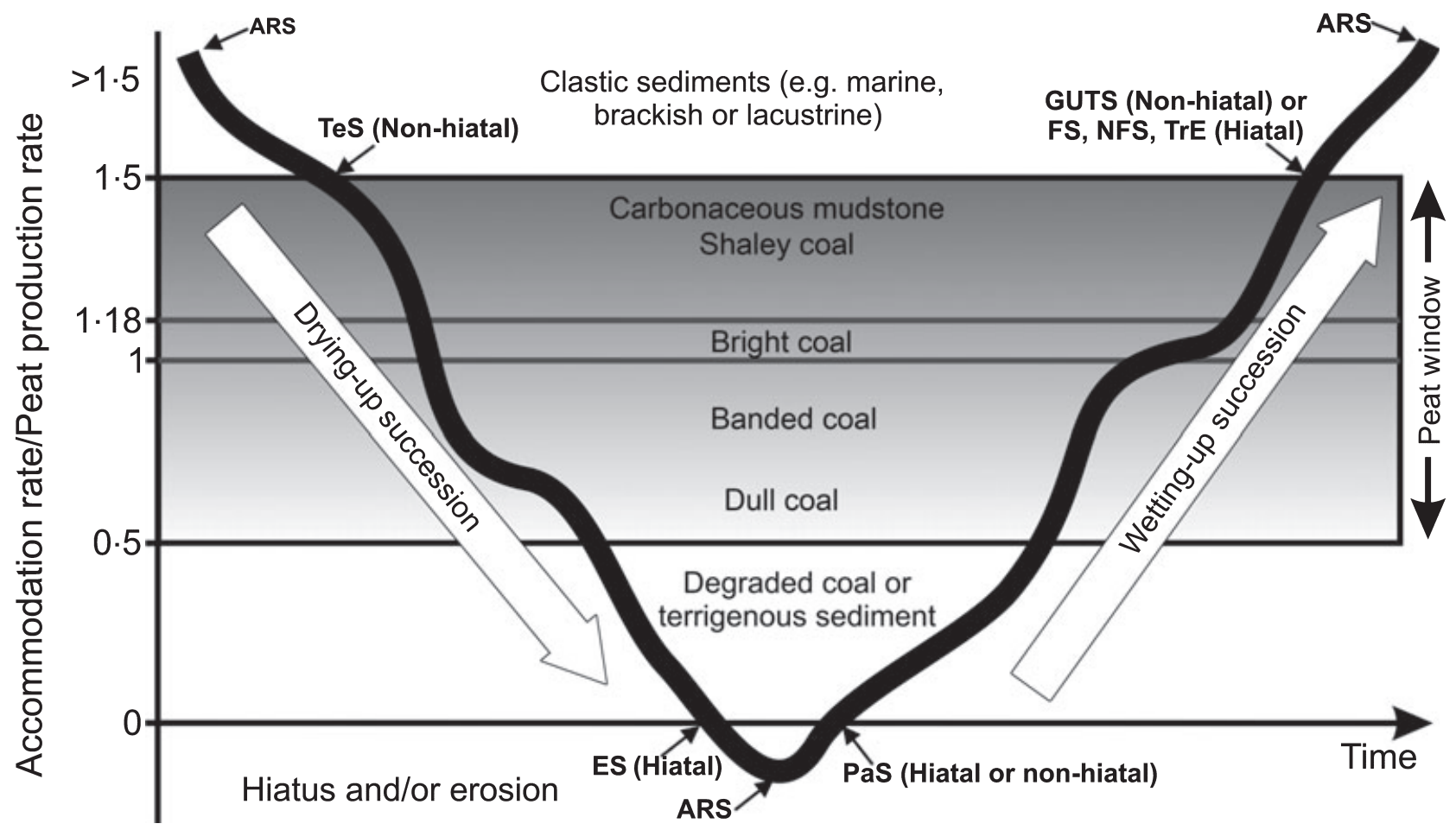

Fig. 1. Idealized curve to show the relationship between accommodation change, peat production, peat facies and resultant coal types. The left-hand limb shows the succession of coal facies deposited during decreasing accommodation; the right-hand limb shows the succession of coal facies deposited during increasing accommodation. The scheme is modified from Wadsworth et al. (2002). 
influx (Diessel et al., 2000). The surface that represents the termination of peat accumulation as it fails to keep up with gradually increasing accommodation defines a give-up transgressive surface (GUTS), which is non-hiatal because peat accumulation is gradually replaced by marine, lagoonal or lacustrine sedimentation (Diessel et al., 2000). If, however, clastic influx is low or there is a sudden increase in accommodation, the transition may be abrupt and the seam is capped by a marine flooding surface (FS) or a lagoonal, lacustrine or terrestrial non-marine flooding surface (NFS) further up depositional dip (Diessel et al., 2000). If there is evidence for removal of peat during transgression, the top of the seam may also represent a transgressive surface of erosion (TrE). The accommodation reversal surface (ARS) represents the inflection point between: (i) a trend of decreasing accommodation, followed by increasing accommodation, which is equivalent to a sequence boundary (SB) if there is evidence for base-level fall or a parasequence boundary if there is not; or (ii) a trend of increasing accommodation, followed by decreasing accommodation which is equivalent to a maximum flooding surface (MFS) or a parasequence flooding surface (Diessel et al., 2000).

To date, one of the most detailed investigations into the sequence stratigraphy of coal seams is the study of Davies et al. $(2005,2006)$ on the Late Cretaceous mid-latitude, Sunnyside coal of the Western Interior Basin, USA. By sampling at high resolution (centimetre-scale) through multiple sections, Davies et al. $(2005,2006)$ were able to discriminate regional-scale accommodation trends from local variability. These authors also demonstrated that key sequence stratigraphic surfaces, including sequence boundaries and parasequence bounding flooding surfaces, could be traced from adjacent and coeval shallow-marine and terrestrial clastic strata into the coal seam, confirming the influence of relative sea-level on accommodation landward of the shoreline. These surfaces were expressed as sharp compositional breaks in the coal, which could be identified along $30 \mathrm{~km}$ of depositional dip. Davies et al. (2006) concluded that the Sunnyside coal provided a more continuous record of accommodation change than the time-equivalent shallow-marine siliciclastic strata, and that changes in inorganic mineral content provided the most reliable method for recognizing accommodation changes in the coal.

This study documents systematic, regional changes in the composition of the Pennsylvanian (Upper Carboniferous) Fire Clay coal of the
Central Appalachian Basin. The Fire Clay coal represents a large mire system $\left(>37000 \mathrm{~km}^{2}\right.$; Outerbridge, 2003) deposited in an equatorial setting (Calder \& Gibling, 1994) during a period when high-magnitude sea-level and climatic fluctuations were occurring (Rygel et al., 2008). Most previous investigations into accommodation changes recorded by coal seams have concerned the Permian onwards (Fig. 2). The key aims of this study are to demonstrate that the record of highfrequency base-level fluctuations can be identified in coal seams: (i) over basin-wide distances $(>100 \mathrm{~km})$; (ii) in the absence of exposed timeequivalent marine or terrestrial clastic strata with which to correlate the base-level changes; and (iii) that accumulated during a period of Earth history when tropical flora differed markedly from Mesozoic and Cenozoic mire communities (DiMichele \& Phillips, 1994). The study also investigates the degree to which coals preserve a continuous record of base-level change.

\section{PALAEOENVIRONMENTAL SIGNIFICANCE OF MACERALS AND MINERALS}

\section{Macerals}

Macerals (Stopes, 1935) are the organic constituents of coal and are analogous to minerals in clastic sediments; they are identified under the microscope on the basis of their reflectance and morphology. The optical properties of macerals vary according to the coal rank (Australian Standard 2856.2-1998, 1998). Photomicrographs of the macerals as identified in the high-volatile-A bituminous Fire Clay coal are provided in Fig. 3. The factors that control the formation of macerals are: (i) the original plant material; (ii) chemical and physical decomposition during peat accumulation; and (iii) physio-chemical coalification during burial and subsidence (Diessel, 1992). The former two factors are related to depositional conditions in the original mire, whereas the latter is unrelated to depositional environment but does not mask the inherent palaeoenvironmental signature of the original peat, except in very high ranks of coal.

Table 1 (compiled from Cohen et al., 1987; Scott, 1989; Diessel, 1992) summarizes the origin and palaeoenvironmental significance of the macerals recognized in this study. Vitrinite macerals, derived from the humification of vascular plant tissue, are interpreted as representing preser- 


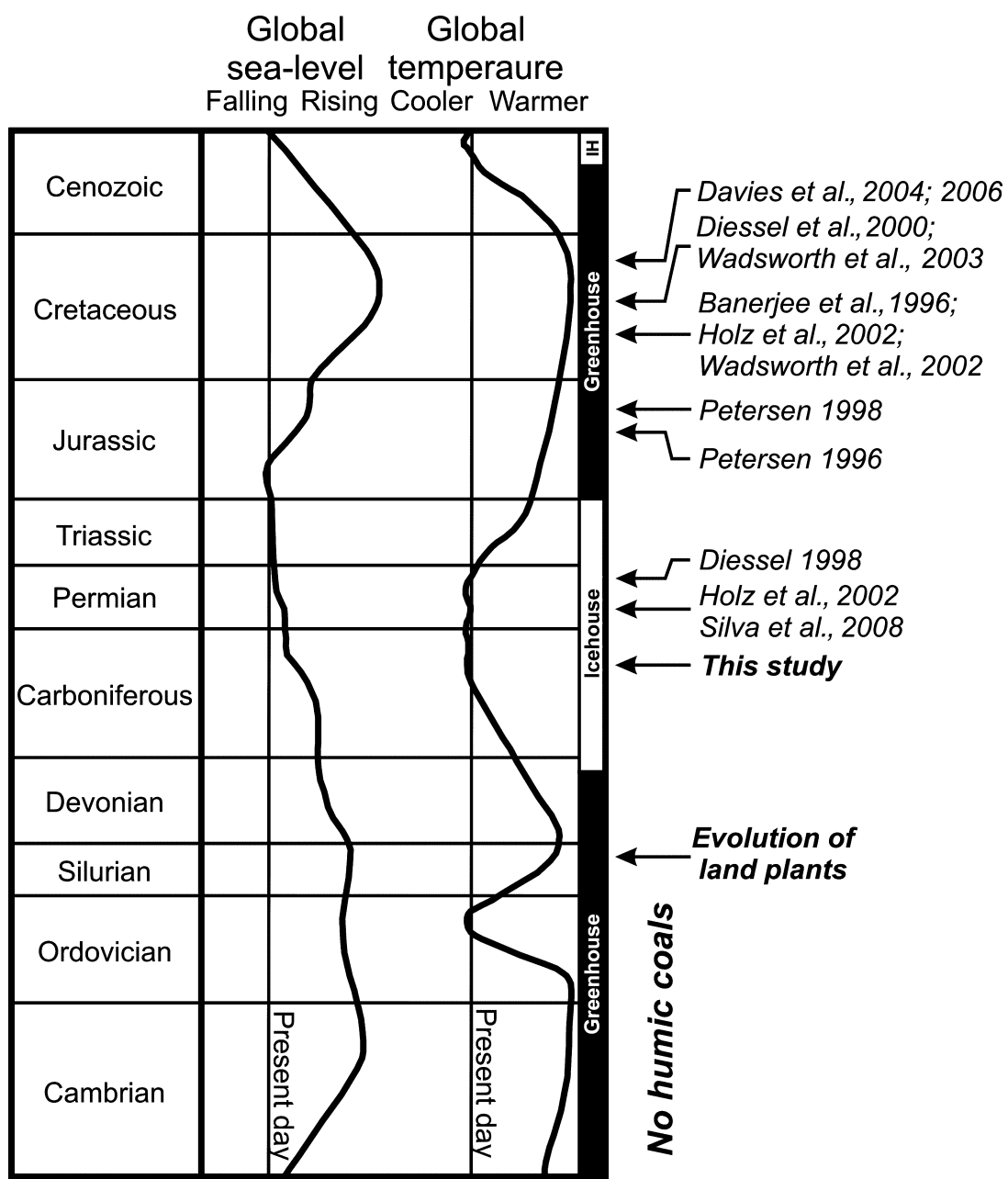

Fig. 2. Schematic global sea-level and climatic curves (from Veevers, 1990), showing the stratigraphic distribution of previous investigations into accommodation changes recorded by coal seams. Detailed sequence stratigraphic studies of Carboniferous coal are under-represented in the existing literature. vation in low $\mathrm{pH}$, anoxic conditions associated with a high water table (Diessel, 1992). Liptinite macerals, derived from hydrogen-rich plant parts such as spores, cuticles and resins, are mechanically resistant and preferentially preserved during reworking and biomass-loss in peat (Diessel, 1992; Petersen et al., 1998). Inertinite macerals are composed of the same plant parts as vitrinite and liptinite, but have undergone primary decomposition under conditions of microbial or fungal oxidation, desiccation or partial combustion in wildfires (Diessel, 1992; Scott \& Jones, 1994; Moore et al., 1996; Scott, 2000); they represent accumulation under conditions of low, fluctuating or oxidizing ground water. Fragmented macerals of any type represent transport or reworking as opposed to well-structured maceral varieties which were well-preserved in situ.

\section{Inorganic minerals}

Among the most widely used criteria to infer the depositional conditions at the peat stage is inorganic mineral content (Cohen et al., 1987; Spears, 1987; Ward \& Swaine, 1995; Davies et al., 2006). Inorganic minerals vary in their composition and consequently in their appearance under reflected light; they commonly exhibit a granular texture, low reflectance and internal reflections (Fig. 3). In present-day mires, biogenic (plant produced) inorganic minerals account for $c a 3 \%$ of the peat (Diessel et al., 2000); coals with inorganic mineral contents considerably greater than this may indicate influx of clastic material into the mire.

Low-lying, rheotrophic (ground water-fed) mires generally accumulate within depressions, and have a high potential to accumulate detrital mineral matter via fluvial or marine inundation, resulting in clastic partings and coals high in inorganic minerals. The concurrence of high detrital minerals and syngenetic pyrite content in coal and peat has been interpreted as indicating the incursion of sediment-laden marine or brackish water into the mire (Cohen et al., 1987; Brown \& Cohen, 1995; Petersen \& Andsbjerg, 

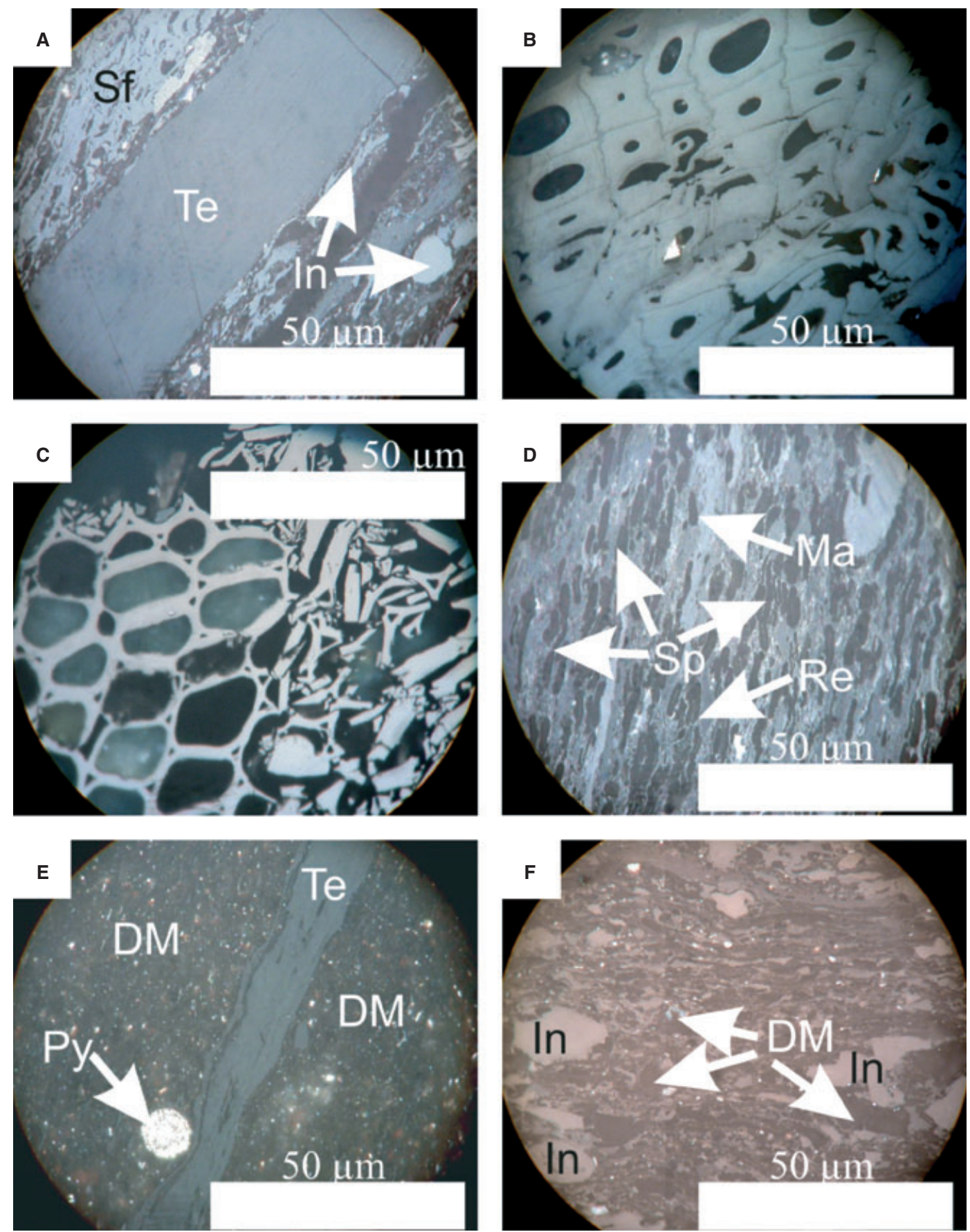

Fig. 3. Photomicrographs showing contrasting maceral and mineral assemblages in the Fire Clay coal. Images were taken in incident white light, oil immersion and one polarizer. (A) Diverse maceral assemblage of structured macerals such as telovitrinite 'Te' and semifusinite 'Sf', fragmented macerals such as inertodetrinite 'In' and micrinite. This association is typical of intermediate accommodation conditions. (B) Semifusinite maceral displaying well-preserved cellular textures. Cell cavities are not filled and have collapsed in the bottom right-hand side of the field of view. (C) Fusinite maceral displaying well-preserved cellular textures. Many cell cavities on the left-hand side of the field of view display white internal reflections indicating that they are mineral-filled. Within-cell mineral material is diagenetic and not considered in this study. (D) Degraded association of abundant sporinite 'Sp', resinite 'Re' and macrinite 'Ma' in a matrix of detrovitrinite and micrinite. This association is typical of low accommodation conditions. (E) Maceral assemblage of detrital minerals 'DM', pyrite 'Py' in framboidal form indicating syngenesis, and telovitrinite 'Te', aligned parallel to bedding. This association is typical of high accommodation conditions. (F) Degraded association of inertodetrinite 'In', micrinite and detrital minerals. The relative abundance of detrital minerals 'DM' in this association is probably caused by extensive reworking and biomass-loss of less resistant peat components during low accommodation conditions.

(C) 2010 The Authors. Journal compilation (ㄷ 2010 International Association of Sedimentologists, Sedimentology 
Table 1. Origin and palaeoenvironmental significance of the macerals and maceral groups recognized in this study.

\begin{tabular}{|c|c|c|c|}
\hline Group & Maceral & Origin & Significance \\
\hline \multirow[t]{2}{*}{ Vitrinite } & Telovitrinite & $\begin{array}{l}\text { Humified stem, root, bark and leaf } \\
\text { tissue, which has survived intact } \\
\text { and displays remnants of cellular } \\
\text { structure }\end{array}$ & \multirow{2}{*}{$\begin{array}{l}\text { High vitrinite content, especially the } \\
\text { structured telovitrinite, indicates a } \\
\text { permanently water-saturated peat } \\
\text { and balanced or high } \\
\text { accommodation creation }\end{array}$} \\
\hline & Detrovitrinite & $\begin{array}{l}\text { Stem, root, bark and leaf tissue } \\
\text { deposited as fine-grained attritus } \\
\text { prior to humification }\end{array}$ & \\
\hline \multirow[t]{3}{*}{ Liptinite } & Sporinite & Resins, fats, waxes and oils & \multirow{3}{*}{$\begin{array}{l}\text { Increased liptinite content indicates } \\
\text { loss of biomass associated with poor } \\
\text { preservation conditions }\end{array}$} \\
\hline & Cutinite & $\begin{array}{l}\text { Cuticles of needles, shoots, stalks, } \\
\text { leaves, roots and stems }\end{array}$ & \\
\hline & Resinite & Resins, fats, waxes and oils & \\
\hline \multirow[t]{5}{*}{ Inertinite } & Micrinite & $\begin{array}{l}\text { Product of disproportionation } \\
\text { reactions, or any other fine-grained } \\
\text { oxidized plant material }\end{array}$ & \multirow{5}{*}{$\begin{array}{l}\text { High inertinite content, especially } \\
\text { structured fusinite and semifusinite } \\
\text { indicate a low or fluctuating mire } \\
\text { water-table and low accommodation } \\
\text { relative to peat production }\end{array}$} \\
\hline & Macrinite & $\begin{array}{l}\text { Jellified plant material which has } \\
\text { undergone some oxidation }\end{array}$ & \\
\hline & Semifusinite & $\begin{array}{l}\text { Partial oxidation of plant material } \\
\text { which has survived intact and } \\
\text { shows remnants of cellular structure }\end{array}$ & \\
\hline & Fusinite & $\begin{array}{l}\text { Plant material which has survived } \\
\text { intact following partial combustion } \\
\text { in wildfires. Shows remnants of } \\
\text { cellular structure }\end{array}$ & \\
\hline & Inertodetrinite & Fragmented semifusinite and fusinite & \\
\hline
\end{tabular}

1996; Staub, 2002). In contrast, ombrotrophic (rain water-fed) mires, which build up above the regional water table, are able to restrict clastic influx topographically. Inorganic mineral yields of $<5 \%$ are characteristic of modern Indonesian domed mires (Polak, 1975; Cameron et al., 1989; Neuzil et al., 1993). Coals with inorganic mineral volumes below $10 \%$ have been interpreted as the products of ancient ombrotrophic mires (Clymo, 1987; Staub, 1991; Diessel et al., 2000; Davies et al., 2005). Some rheotrophic mires, however, can develop peats low in inorganic minerals (McCarthy et al., 1989) because clastic sources are largely absent, or because the mire is broad enough to buffer influx from the clastic system (Diessel et al., 2000; Greb et al., 2002b). Oxidative biomass-loss from peat can concentrate inorganic mineral material into discrete layers (McCabe, 1991). In this case, the association of inorganic minerals with other indications of oxidation and reworking, such as fine-grained inertinite macerals might be expected (for example Fig. 3F). Aeolian transport of clastic material into the original mire may contribute additional inorganic mineral matter to peat (Warwick, 2005).

\section{GEOLOGICAL SETTING}

The Central Appalachian Basin (Fig. 4) was a depocentre within the Variscan-Alleghanian foreland, which subsided in response to thrust-sheet loading in the hinterland to the south-east (Tankard, 1986). Throughout the Pennsylvanian, predominantly feldspathic siliciclastic debris eroded from this hinterland and prograded westward into the basin in a succession of delta systems, which onlapped against the contemporaneous Cincinnati-Waverly arch (structural high) to the north-west (Quinlan \& Beaumont, 1984; Englund \& Thomas, 1990). Fluvio-deltaic sedimentation was punctuated by regular, cyclic marine incursions from the south and west due to glacio-eustatically driven fluctuations in global sea-level of up to $100 \mathrm{~m}$ (Chesnut, 1994; Greb et al., 2008; Rygel et al., 2008). Throughout this time, the basin passed northwards through an equatorial, humid climatic zone that ranged from ever-wet to seasonally wet (Scotese \& McKerrow, 1990; Calder \& Gibling, 1994). Tropical flora at this time was dominated by lycopods and treefern species, which contributed minor amounts 


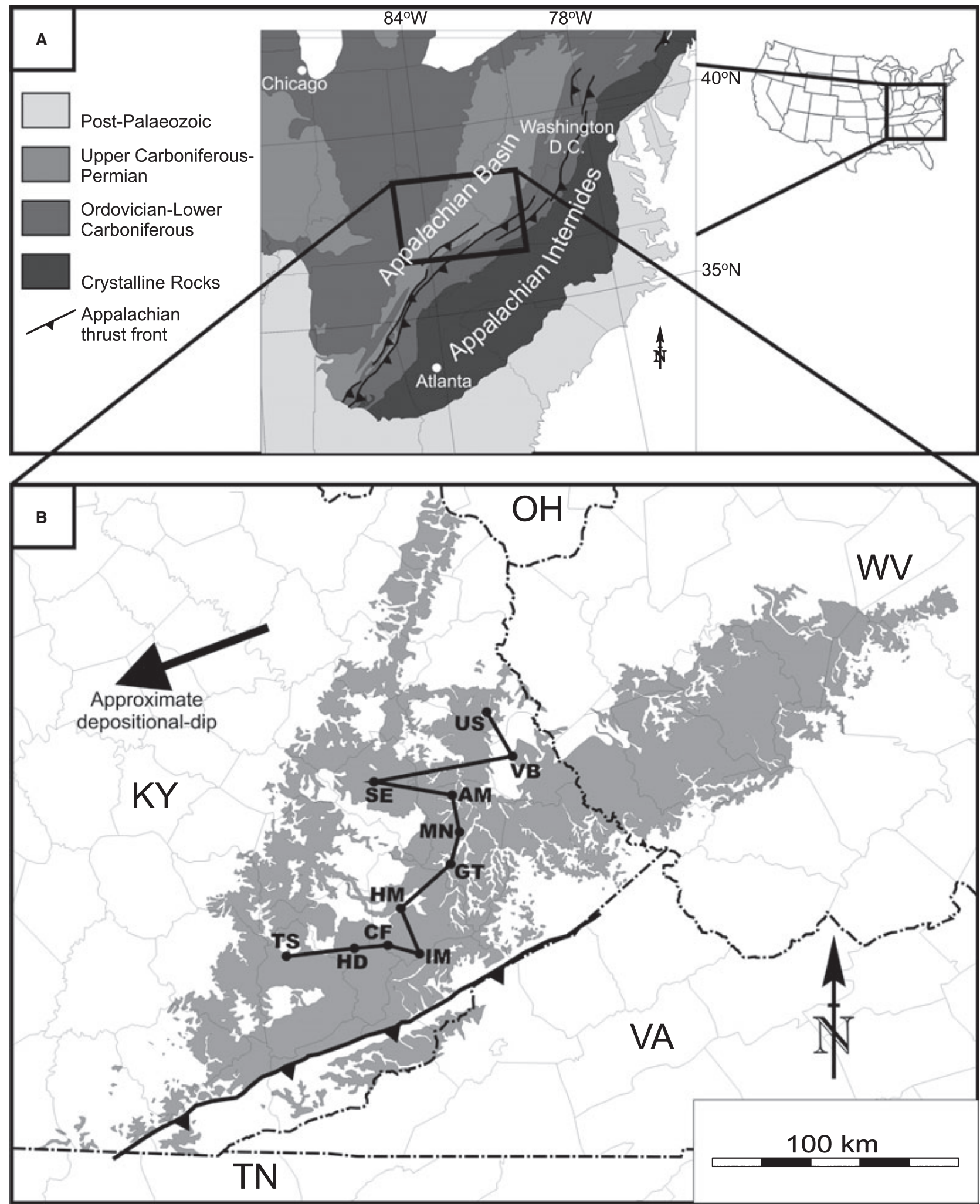

Fig. 4. (A) Location of the Appalachian Basin and the study area in the eastern USA. (B) Map of the approximate post-erosional extent of the Fire Clay coal zone in the Central Appalachian Basin (shown in grey; modified from Tewalt et al., 2001), showing the location of the sampled sections through the coal. The names of the sampled sections are abbreviated as follows: TS, Thousandsticks; HD, Hazard; CF, Carr Fork Lake; IM, Isom; HM, Hindman; GT, Garrett; MN, Martin; AM, Abbot Mountain; SE, Salyersville; VB, Venter's Bridge; US, Ulysses. The line of crosssection illustrated in Figures 9 and 10 is also shown. 
of woody material to the peat (DiMichele \& Phillips, 1994). Consequently, mires that accumulated during this period may have been inherently different from those later in the geological record in terms of their accumulation rates and compaction ratios.

The Breathitt Group (Chesnut, 1992) of the Central Appalachian Basin comprises up to $1 \mathrm{~km}$ of Namurian to Westphalian (lower to midPennsylvanian) coal-bearing coastal plain, marine and fluvial strata (Chesnut, 1992; Aitken \& Flint, 1994, 1995; Martino, 1996). Chesnut (1992) identified five lithostratigraphic formations within the upper Breathitt Group (the Grundy, Pikeville, Hyden, Four Corners and Princess Formations) separated by four major, regional marine members (the Betsie Shale, Kendrick Shale, Magoffin and Stoney Fork Members; Fig. 5). The Betsie Shale and Magoffin Members are equivalent to the European Anthracoceratites vanderbeckei and Anthracoceras aegiranum marine biozones (Riley \& Turner, 1995), which define the base and top of the Westphalian B (Duckmantian), respectively (Fig. 5). On this basis, fossiliferous, condensed mudstone units or limestone beds within the major marine members have been interpreted as containing third-order (1 to $1.5 \mathrm{Ma}$ frequency) maximum flooding surfaces of major depositional sequences (Fig. 5; Aitken \& Flint, 1994, 1995). This study is focussed on the Fire Clay coal in the Hyden Formation of the Upper Breathitt Group (Fig. 5). Further descriptions of the sedimentology, depositional environments and sequence stratigraphy of the Breathitt Group can be found in Cobb et al. (1981), Chesnut (1992, 1994), Aitken \& Flint (1994, 1996) and Martino (1996).

In the field area, the Hyden Formation is composed of four to six high-order depositional sequences ('coal-clastic cycles' of Chesnut, 1992; Figs 5 and 6), each typically 10 to $30 \mathrm{~m}$ thick. The generic aspects of these sequences are modified from Aitken \& Flint $(1994,1995)$. The lowstand systems tract (LST) and transgressive systems tract (TST) comprise incised valley-fills of sharpbased medium to coarse-grained trough crossbedded fluvial sandstones that grade upward through tabular cross-bedded fine-grained sandstones into heterolithic strata that display lateral accretion surfaces (Fig. 6). Palaeocurrent orientations from the fluvial sandstones indicate that depositional dip was to the north-west and southwest (Chesnut, 1994; Aitken \& Flint, 1995; Martino, 1996; Greb et al., 1999a). A laterally extensive coal bed or zone caps the incised valley-fills and laterally adjacent, interfluve pal- aeosol surfaces. Major coals or coal zones were assigned to the TST or maximum flooding zone (MFZ) on the basis that peat accumulation was largely able to keep up with high accommodation rates and clastic sedimentation was most likely to be confined to the margins of the basin at this time. This interpretation is consistent with the sequence stratigraphic position inferred for most coals in the geological record (Diessel, 2007). The highstand systems tract (HST) is characterized by a coarsening-up succession of fine-grained marine, brackish or terrestrial strata that grade upward into heterolithic coastal plain overbank sediments, single storey sandstone-filled channels and poorly developed coals and palaeosols (Fig. 6). Lack of outcrop exposure in more distal parts of the basin precludes the identification of the falling stage systems tract (FST) and erosion on the overlying sequence boundary commonly removes much of the HST.

Within this regional framework Aitken \& Flint (1995) interpreted the Fire Clay coal as being positioned within the late LST or early TST of a high-order depositional sequence in the Hyden Formation (Figs 5 and 6) and this is the thickest and most laterally extensive coal of the formation. It is up to $3 \mathrm{~m}$ thick and crops out over an area $>37000 \mathrm{~km}^{2}$ in eastern Kentucky, south-west West Virginia, western Virginia, and northeastern Tennessee (Fig. 4B; Tewalt et al., 2001; Outerbridge, 2003), assuming different names across different parts of the basin (Chesnut, 1992; Rice \& Hiett, 1994). The Fire Clay coal is considered by previous authors to have accumulated in a delta-plain setting (Eble \& Grady, 1990; Aitken \& Flint, 1994), but a correlative, coeval shoreline is not exposed. A dark grey/brown, claystone gley palaeosol with rootlets underlies the seam, and it is overlain by floodplain overbank heterolithic strata and mudstones containing rare marine to fresh water invertebrate fauna (Cobb et al., 1981; Chesnut, 1991). Across much of the study area, the Fire Clay coal is overlain sharply by fine to coarse-grained fluvial sandstones that, although showing a planar contact with the top of the coal, represent the fill of younger incised valleys that cut down from a higher stratigraphic position and belong to the overlying sequence (Fig. 6; Aitken \& Flint, 1994, 1995). Locally, incised valleys truncate and remove the Fire Clay coal completely (Greb et al., 1999a). The seam contains a distinctive clastic parting (Fig. 7), which is present across much of the basin (Outerbridge, 2003), and provides a high degree of confidence when correlating between 


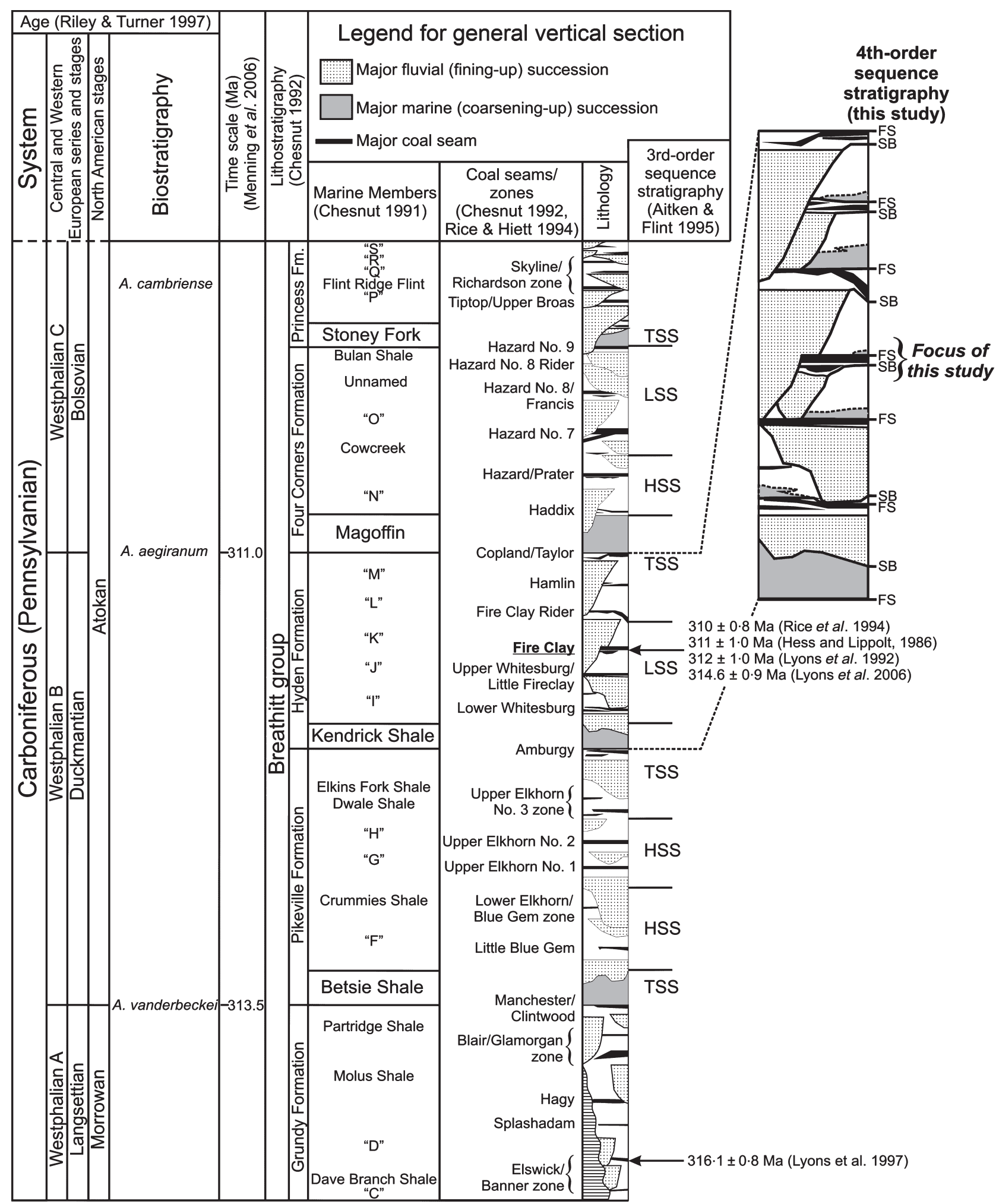

Fig. 5. Age, lithostratigraphic nomenclature and sequence stratigraphy of the Upper Breathitt Group, as exposed in the eastern Kentucky portion of the Central Appalachian Basin.

sampled sections. The occurrence of sanidine phenocrysts, euhedral zircons and Fe-Ti minerals such as ilmenite and rutile within the parting, have led to its interpretation as an altered volcanic ash-fall (tonstein) horizon (Bohor \& Triplehorn, 1981; Lyons et al., 1992). ${ }^{40} \mathrm{Ar} /{ }^{39} \mathrm{Ar}$ 

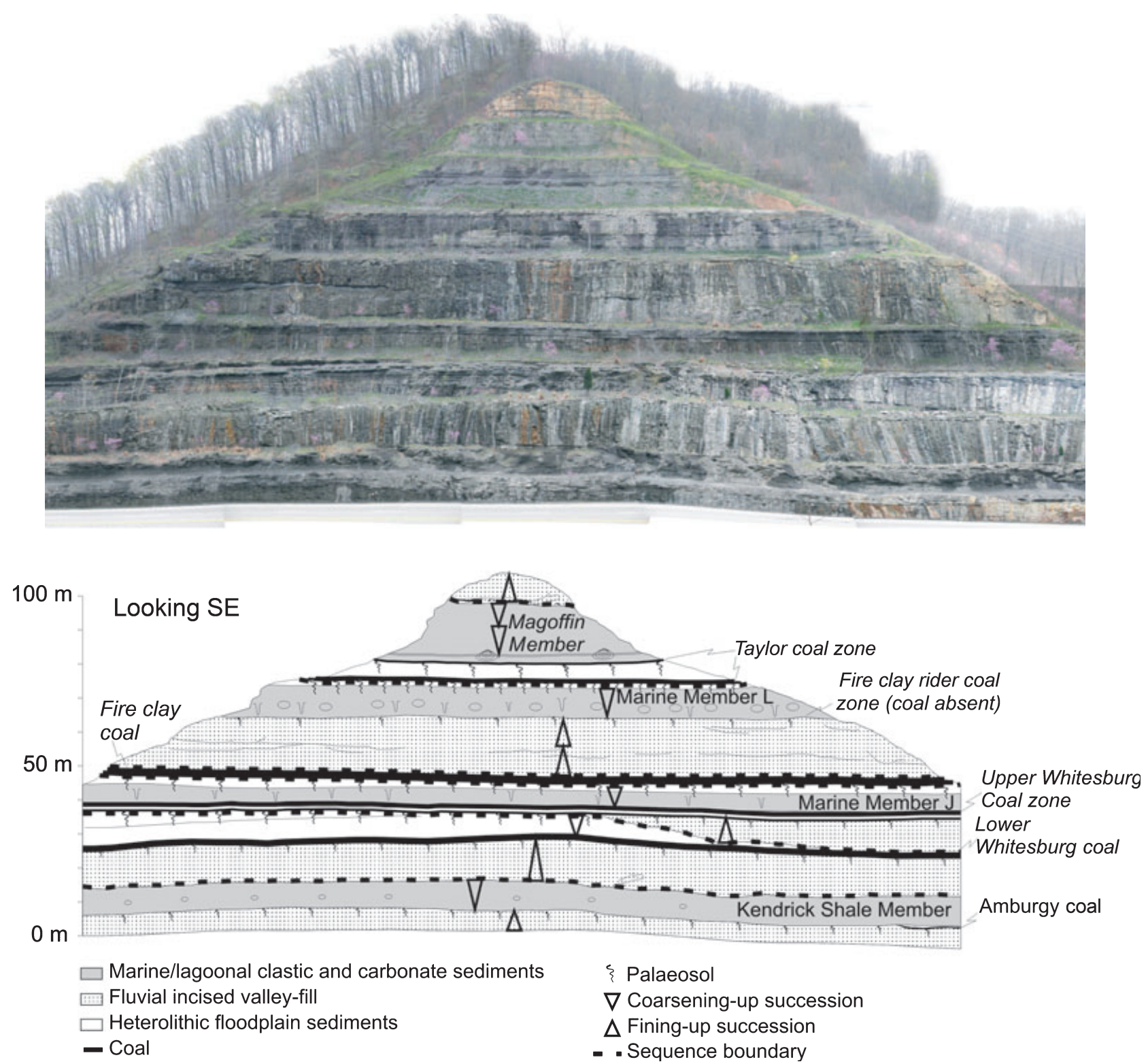

Fig. 6. Photomontage of a road-cut exposure of the Hyden Formation at Garrett (see Fig. 4); and interpretative sketch showing major lithologies and the sequence stratigraphic framework of the formation. Note that above the Lower Whitesburg coal and the Fire Clay coal incised valleys cut down to, but not through the coal seam.

analyses on sanidines from the ash-fall have yielded absolute age dates of $311 \pm 1 \cdot 0 \mathrm{Ma}$ (Hess \& Lippolt, 1986), $312 \pm 1 \cdot 0 \mathrm{Ma}$ (Lyons et al., 1992) and $310 \pm 0 \cdot 8 \mathrm{Ma}$ (Rice et al., 1994), whereas zircons from the ash-fall have been dated at $314 \cdot 6 \pm 0.9 \mathrm{Ma}$ (Lyons et al., 2006), broadly consistent with biostratigraphy in the upper Breathitt Group.

Previous studies of the Fire Clay coal recognize that it comprises a succession of stacked coal 'benches', separated by persistent clastic partings (including the volcanic ash-fall horizon), oxidized and/or degraded coal horizons (Eble \&
Grady, 1990; Eble et al., 1994; Greb et al., 1999a,b,c, 2002b). Bench-scale (10 to $30 \mathrm{~cm}$ ) petrographic, palynological and geochemical analyses of the Fire Clay coal indicate that the benches represent separate mires that accumulated under different environmental conditions and hydrological regimes, including low-lying rheotrophic mires restricted to topographic depressions, and regionally widespread domed, ombrotrophic mires (Eble \& Grady, 1990; Eble et al., 1994; Greb et al., 1999a, 2002b). The petrographic data set presented herein is of a higher resolution than previous studies (with an average 

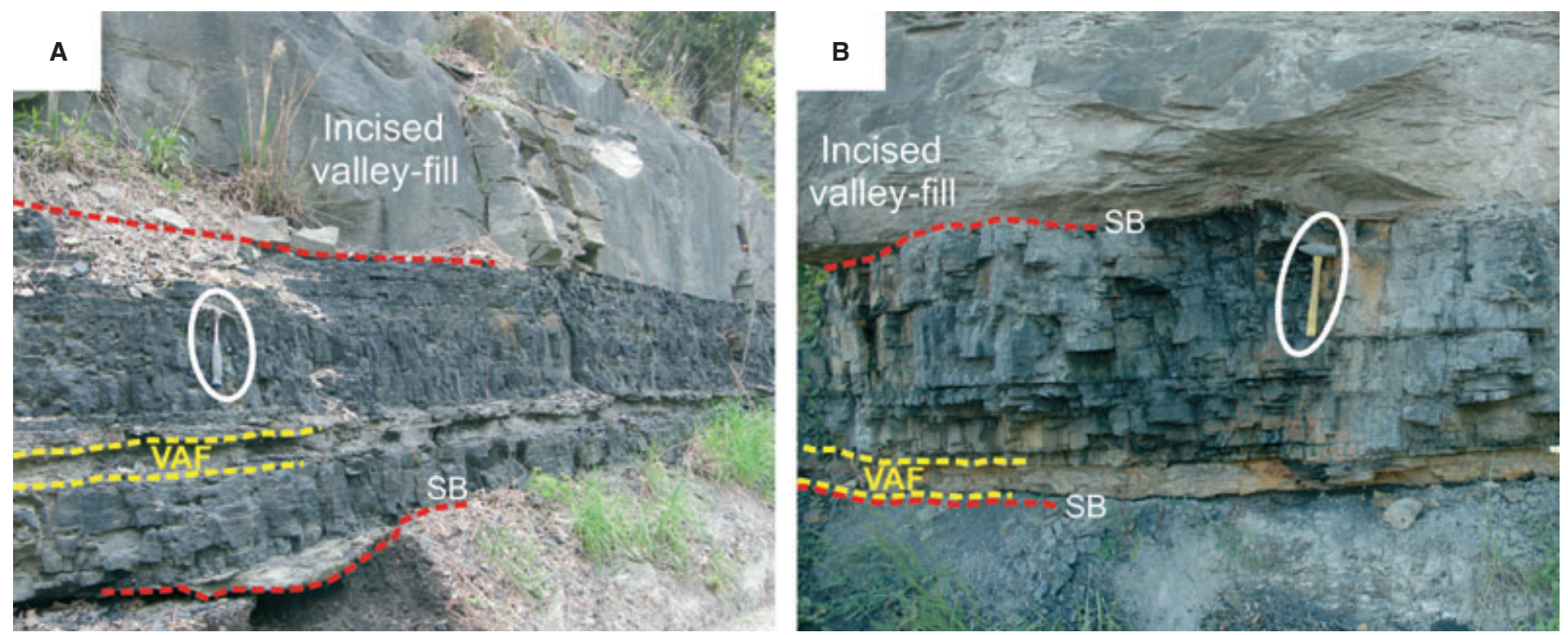

Fig. 7. Outcrop photographs of the Fire Clay coal. (A) Volcanic ash-fall (VAF) within the Fire Clay coal at the roadcut section along the Ky15 near Isom and (B) at the base of the Fire Clay coal at the road-cut section along the Ky15 at Hazard. 'SB' sequence boundary. Note that hammers for scale (circled) are $33 \mathrm{~cm}$ long.

sample spacing of $2 \cdot 7 \mathrm{~cm}$ ), allowing the analysis of more detailed changes in mire evolution within the component 'benches' of the Fire Clay coal.

\section{SAMPLING AND ANALYTICAL PROCEDURE}

Eleven outcrops of the Fire Clay Coal were selected from a series of road-cut, abandoned mine wall and natural exposures across more than $100 \mathrm{~km}$ in eastern Kentucky (Fig. 4B). Centimetre-scale sedimentary logging of the encasing sedimentary strata was carried out at each locality, recording the full range of grain sizes, sedimentary structures, body and trace fossils observed at outcrop. At each locality, the coal bed was cut back by up to $0.5 \mathrm{~m}$ to remove excessively weathered material and a coal lithotype log was produced to ensure that important lithological surfaces were identified prior to sampling.

In total, 275 coal samples were recovered, representing the whole coal bed thickness at each locality. Whenever possible, the specimens were removed intact such that their internal stratigraphy could be preserved. The average thickness of each specimen was $c a 2 \cdot 7 \mathrm{~cm}$.

The samples were subsequently cured in epoxy resin, cut perpendicular to layering and polished in accordance with standard methods for incident light microscopy. A minority of samples which were too brittle to be removed intact (seven) were crushed to a maximum grain size of $2 \mathrm{~mm}$, and a representative grain-mount produced instead. The maceral and mineral composition of each sample was determined by counting 500 points per sample, in accordance with Australian Standard guidelines (Australian Standard 2856.21998, 1998).

\section{RESULTS}

Table 2 gives the average composition of the Fire Clay coal for each of the sampled sections, as well as the overall average for all 275 maceral and mineral analyses. The mean detrital mineral content of $10.7 \%$ indicates that periods of significant clastic input into the original mires occurred. Bulk detrital mineral content does not increase in the basinward sampling localities, suggesting that clastic material was not marine derived (Davies et al., 2005). This interpretation is supported by the low mean pyrite content of $0.1 \%$ which suggests that mire ground water was predominantly fresh. The mean vitrinite to inertinite ratio of $\mathrm{ca} 3 \cdot 5: 1$ indicates that accommodation and peat production were wellbalanced during the accumulation lifetime of the mires.

\section{Evaluation of indicators of accommodation change}

This study makes use of maceral and mineral associations as palaeoenvironmental indicators in order to limit bias caused by ambiguities in the 

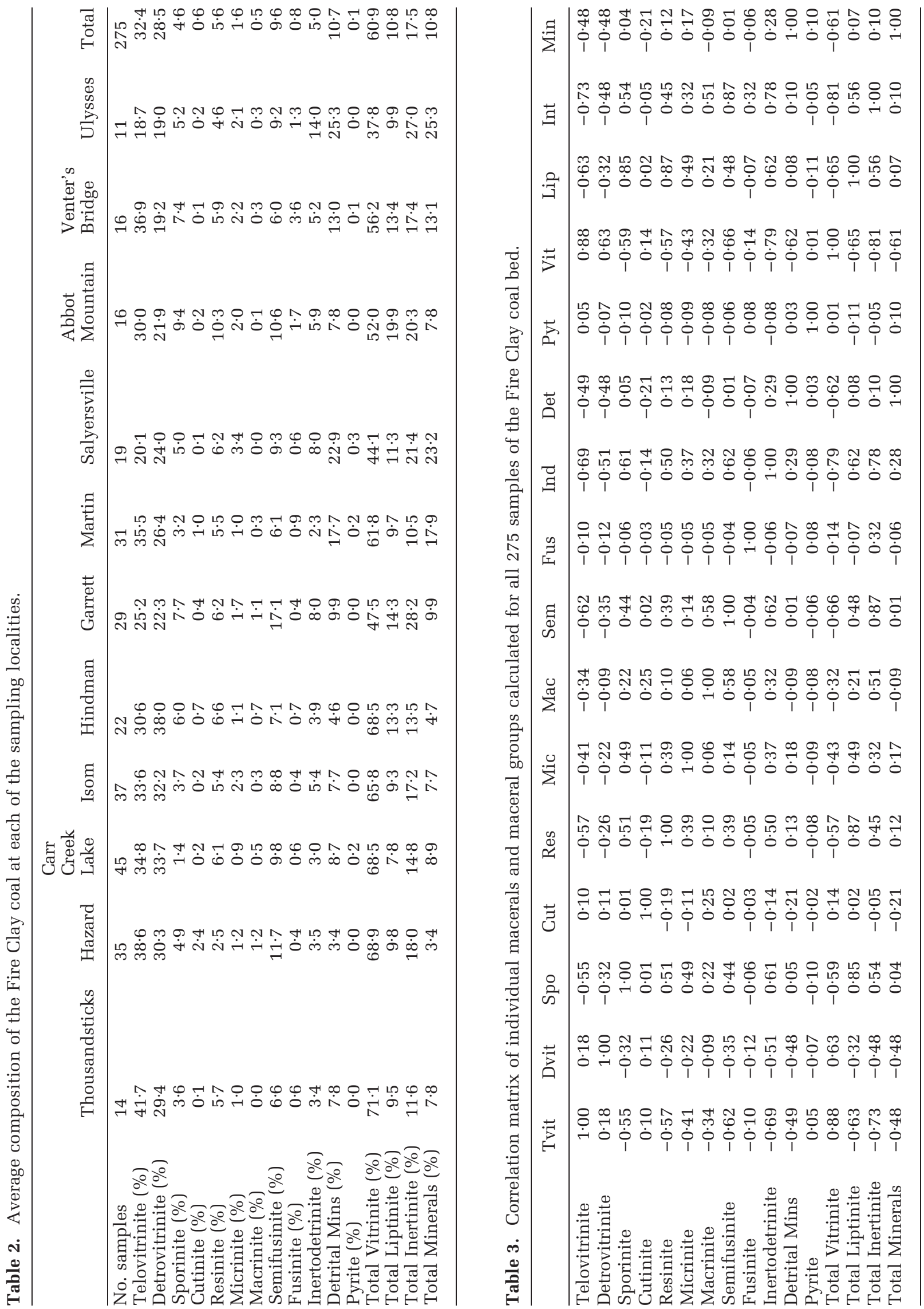

(C) 2010 The Authors. Journal compilation (c) 2010 International Association of Sedimentologists, Sedimentology 
interpretation of individual macerals and minerals (Diessel \& Gammidge, 1998; Diessel et al., 2000; Greb et al., 2002b). The four peat facies of Teichmüller (1950), the double triangle of Hacquebard \& Donaldson (1969), the tissue preservation index of Diessel $(1985,1986)$ and the ground water influence index of Calder (1991) are other examples of this type of approach.

Table 3 shows the correlation coefficients for maceral, and mineral and maceral groups computed from all 275 samples of coal analysed. Macerals from the same group commonly show positive relationships, as their similar properties respond in the same manner to the same chemical and physical processes occurring in the mire. Generally, the results show modest correlation trends, indicating complicated interactions of different processes at different times during the accumulation of the peat.

As the process of oxidation occurs at the expense of humification, vitrinite and inertinite display a strong negative association $(-0 \cdot 81)$. Liptinite group macerals associate with inertinites $(+0 \cdot 56)$ rather than with vitrinites $(-0 \cdot 65)$, indicating that reworking and biomass-loss (which preferentially concentrates the mechanically resistant liptinites) occurred during mire oxidation. The negative association between vitrinite and detrital mineral content $(-0.61)$ is interpreted as an artefact of the dominance of vitrinite throughout most of the coal, rather than that clastic input and humification of plant material occurred during different depositional conditions. Detrital minerals are an adventitious component of peat, and are gained in the peat at the expense of organic material through inundation of the mire during times of high accommodation. In the Fire Clay coal, this is clearly expressed by the frequent association of detrital minerals with structured vitrinite, and the layered nature of quartz and clay minerals observed under the microscope, which indicate suspension fall-out (Fig. 3E). Increased detrital mineral content is also associated with increased inertinite and liptinite (Fig. 3F), suggesting that detrital minerals are concentrated further by the oxidative loss of organic material during times of low accommodation. In contrast to the study of Davies et al. (2005, 2006), detrital mineral content does not provide a reliable proxy for accommodation changes recorded in the Fire Clay coal, although low detrital mineral content may be indicative of conditions of balanced accommodation.

Vitrinite and inertinite content are considered to be the best indicators of accommodation change. Liptinite provides an indication of reworking and biomass-loss, whilst detrital mineral content provides an indication of balanced versus unbalanced accommodation conditions.

\section{Correlation of petrographic trends across the study area}

Vertical profiles of vitrinite, inertinite, liptinite and detrital mineral content for each of the 11 sampled sections can be plotted and correlated (Fig. 8A to D). Maceral percentages are calculated on a mineral-free basis. The correlation is supported by the recognition of the volcanic ash-fall horizon at eight of the sampling localities. Because the ash-fall was a geologically instantaneous event, its upper surface has been used as a datum, but does not necessarily represent a flat depositional surface. The study of Crowley et al. (1994) on a Cretaceous tonstein from Utah, USA highlighted ambiguities regarding changes in ground water geochemistry induced by the introduction of volcanic ash into peat, which could alter the coalification pathway of maceral precursors. For this reason, the volcanic ash-fall is omitted from the petrographic study.

\section{Interpretation of depositional processes, mire environments and accommodation trends}

A striking feature of both this coal and others in the central Appalachian Basin is the presence of several abrupt vertical discontinuities in the composition of the seam (Staub, 1991, 2002; Greb et al., 1999a, 2002b). These abrupt shifts can be correlated over much of the study area and define what are interpreted as time-equivalent units (Units 1 to 6; Fig. 8) analogous to the 'benches' of Greb et al. (1999a, 2002b). The different units show similar internal petrographic trends, have characteristic petrographic properties (Table 4) and markedly different aerial distributions. The field characteristics, petrography, interpreted depositional conditions and accommodation trends of each unit are outlined below.

\section{Unit 1}

Description: Unit 1 is up to $0.26 \mathrm{~m}$ thick and forms the basal part of the coal at Garrett and Salyersville (Fig. 8), where it has a sharp contact with the underlying rooted claystone. It is characterized by overall high detrital mineral, liptinite and inertinite content $(20 \cdot 8 \%, 17.9 \%$ and $25.8 \%$, respectively; Table 4 ). Vertical trends 


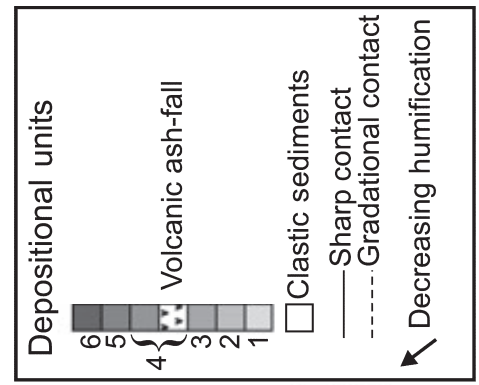

एuㅣ 譬

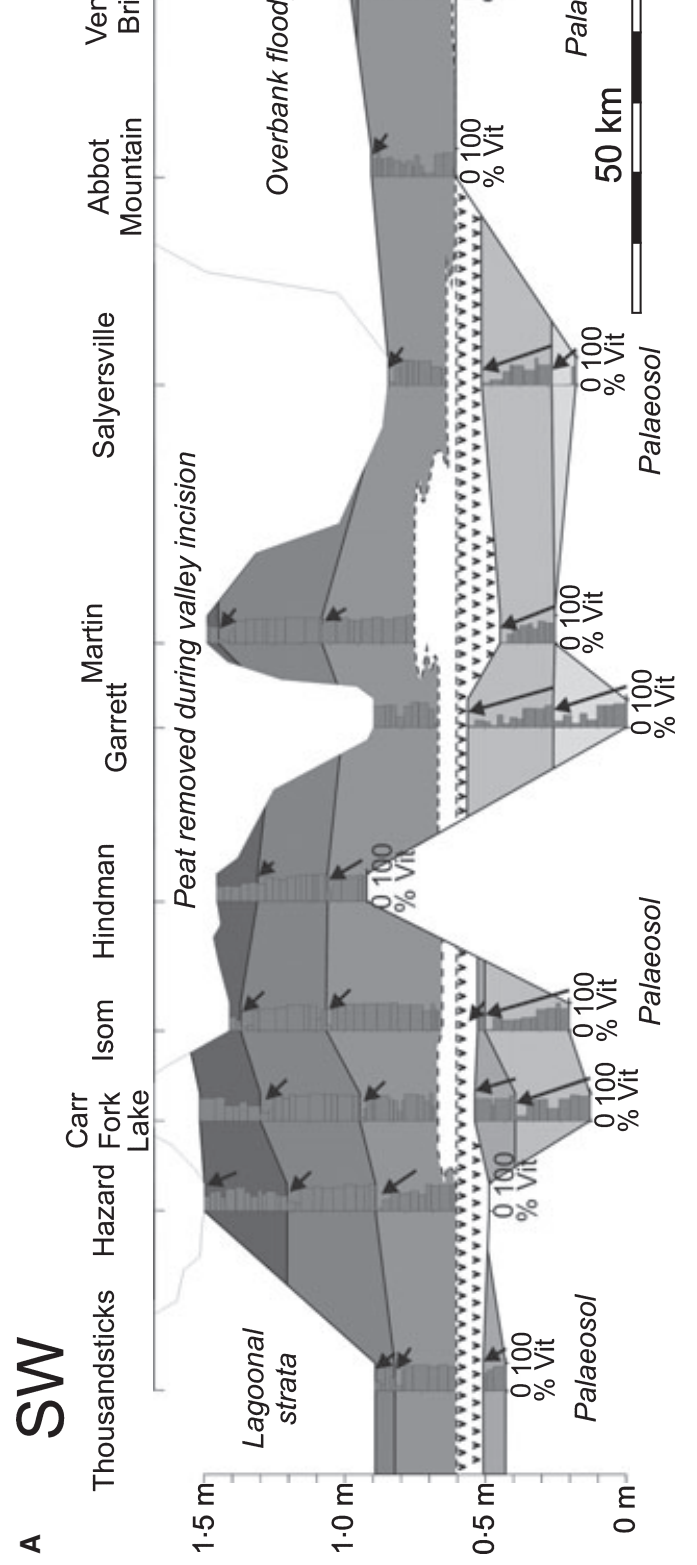

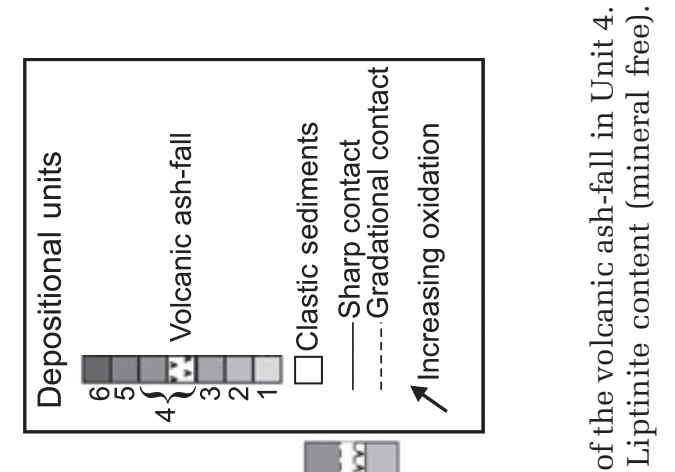

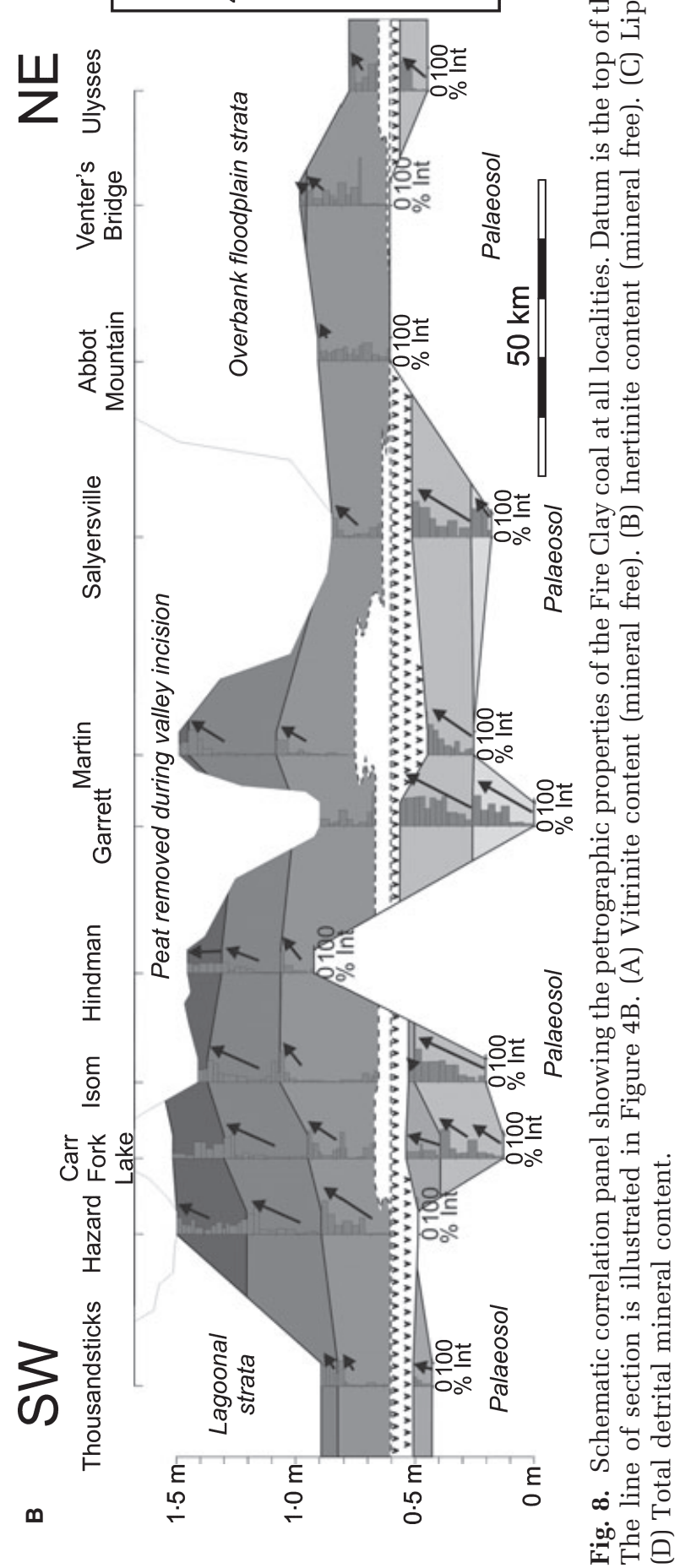



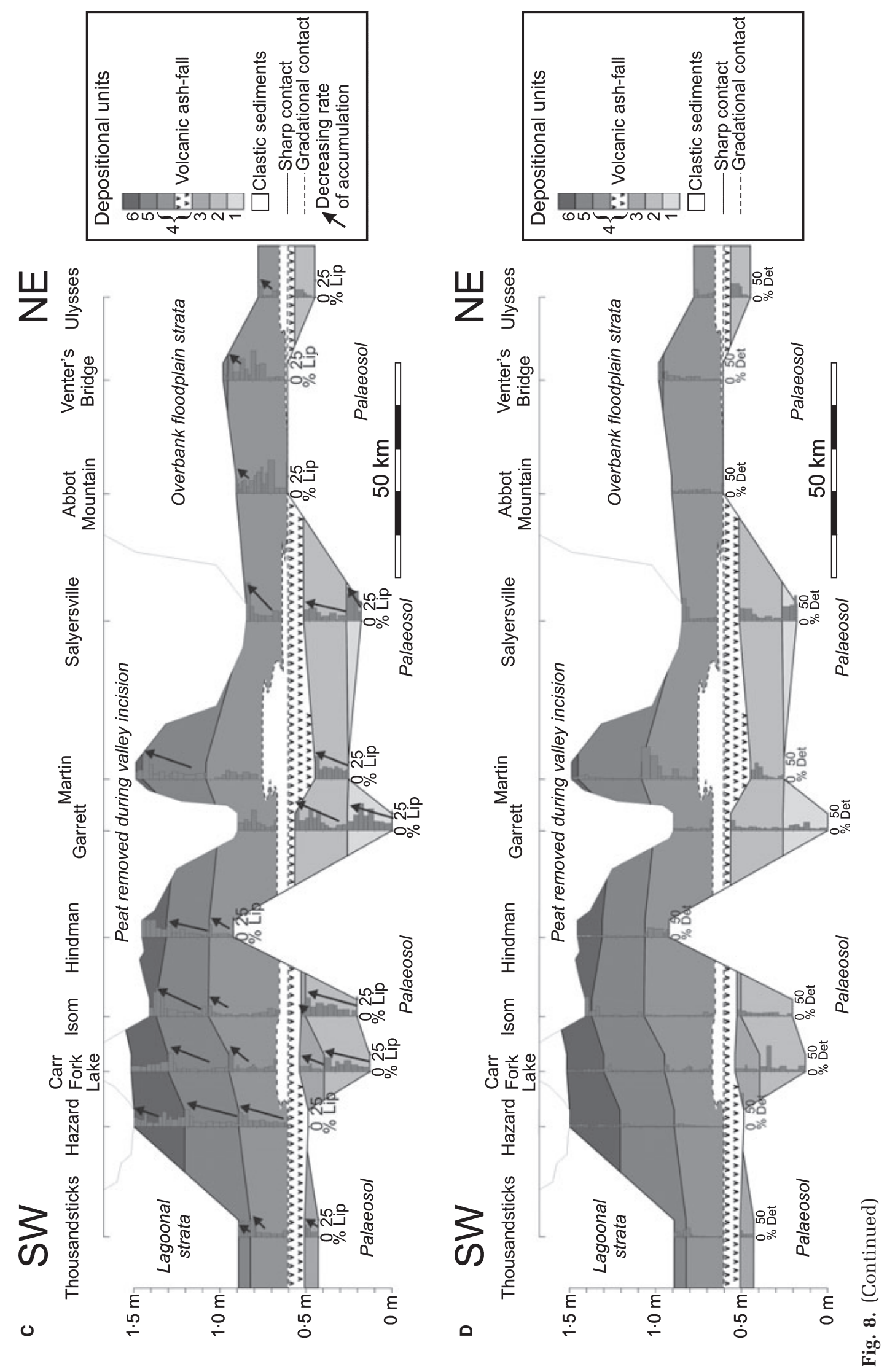

(C) 2010 The Authors. Journal compilation (c) 2010 International Association of Sedimentologists, Sedimentology 


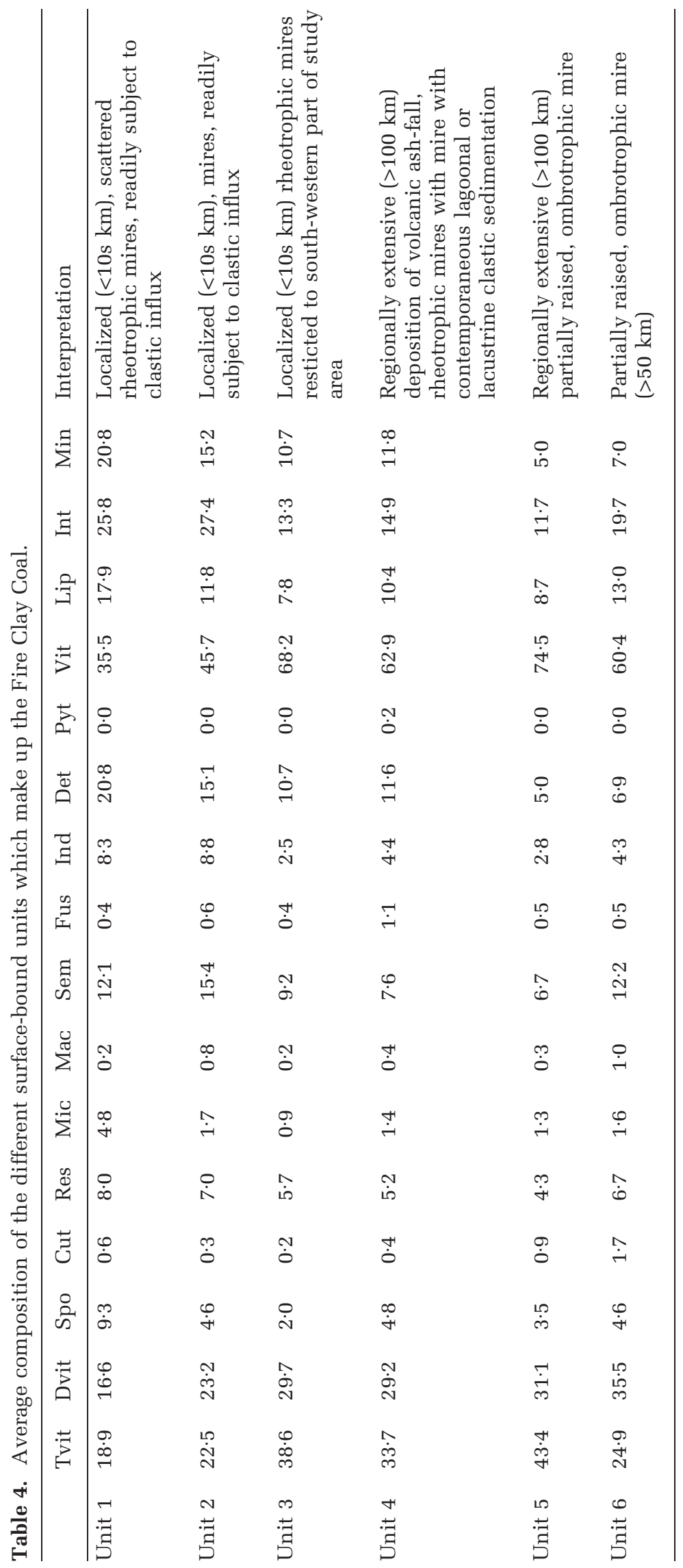


consistent through the unit show an upward decrease in total vitrinite and an associated increase in total inertinite and liptinite.

Interpretation: The localized distribution of Unit 1 is interpreted as representing deposition of peat in one or more isolated topographic hollows (Greb et al., 1999a). The high content of transported material (detrital minerals and liptinite) suggests that Unit 1 represents a planar peat deposited under rheotrophic conditions, readily subject to inundation. The vertical petrographic trends within Unit 1 record increasing processes of oxidation, reworking and biomass-loss. Unit 1 therefore represents a drying-up succession (Fig. 9).

\section{Unit 2}

Description: Unit 2 sharply overlies Unit 1 at Garrett and Salyersville. At Carr Fork Lake, Isom, Martin and Ulysses, where it forms the basal unit of the coal seam, Unit 2 has a sharp contact with the underlying rooted claystone (Fig. 8). The unit attains a maximum thickness of $0.3 \mathrm{~m}$ at Garrett. The unit is characterized by high total inertinite $(27 \cdot 4 \%)$, moderate liptinite $(11 \cdot 8 \%)$ and detrital minerals $(15 \cdot 2 \%$; Table 4$)$. Unit 2 shows similar vertical trends to Unit 1, with an upward decrease in total vitrinite, accompanied by an upward increase in total inertinite and liptinite. There is also an increase in total detrital minerals at the top of the unit.

Interpretation: Unit 2 records a phase of peat accumulation over a wider area than Unit 1 . Moderate total liptinite and detrital minerals suggest that this peat, too, was planar, rheotrophic and subject to allochthonous inputs. The vertical petrographic profile of Unit 2 displays a trend of gradually increasing oxidation, interpreted as a response to decreasing accommodation. The higher detrital mineral concentration at the top of the unit is likely to represent oxidative biomass-loss, rather than an increase in imported clastic material. Unit 2 is interpreted as a dryingup succession (Fig. 9).

\section{Unit 3}

Description: Unit 3 is found only in the southwestern part of the study area, overlying Unit 2 at Carr Fork Lake and Isom and forming the basal part of the coal seam at Thousandsticks, where it has a sharp contact with the underlying rooted claystone (Fig. 8). Unit 3 is up to $0 \cdot 15 \mathrm{~m}$ thick and contains a large amount of vitrinite $(68.2 \%)$, moderate amounts of detrital minerals $(10 \cdot 7 \%)$ and low amounts of liptinite (7.8\%; Table 4). Vitrinite content decreases upwards, whilst inertinite, liptinite and detrital mineral content increase upwards.

Interpretation: The consistently high vitrinite content indicates that mire conditions were planar and rheotrophic. Vertical petrographic trends indicate that peat accumulation occurred during decreasing accommodation. Unit 3 therefore represents a drying-up succession (Fig. 9).

\section{Unit 4}

Description: Unit 4 is present throughout the whole study area. It comprises a basal volcanic ash-fall horizon (Bohor \& Triplehorn, 1981; Lyons et al., 1992) that grades upward into carbonaceous laminated claystone and coal. Unit 4 sharply overlies Unit 2 at Garrett, Martin, Salyersville and Ulysses, Unit 3 at Thousandsticks, Carr Fork Lake and Isom, and a rooted palaeosol at Hazard, Hindman, Abbot Mountain and Venter's Bridge (Fig. 8). Unit 4 forms the top of the Fire Clay coal seam at Abbot Mountain and Ulysses, where it is sharply overlain by lagoonal, bay-fill or floodplain claystones, siltstones and sandstones. The ash-fall horizon is up to $0 \cdot 16 \mathrm{~m}$ thick at Martin and readily identified in the field as a hard, massive or crumbly grey-brown claystone with a conchoidal fracture. A basal 'lag' consisting of flecks and stringers of coalified plant material is typically aligned parallel to bedding. The overlying coal and clastic sediments contain reworked fragments of the ashfall. The coal portion of Unit 4 contains moderate vitrinite $(62 \cdot 9 \%)$, low liptinite $(10 \cdot 4 \%)$, low inertinite $(14.9 \%)$ and low detrital minerals $(11.6 \%)$. Unit 5 is the only unit to show significant syngenetic pyrite content $(0 \cdot 2 \%$; Table 4$)$. The top of the unit is marked by a decrease in vitrinite and an increase in inertinite, liptinite and detrital minerals (Fig. 8). However, at localities north-east of Salyersville, the petrographic trends are not readily correlatable to localities further to the southwest, with petrographic trends appearing to be reversed at Abbot Mountain and Venter's Bridge. This observation casts some uncertainty on the validity of the correlation of Unit 4 at the Abbot Mountain and Venter's Bridge localities, where the distinctive volcanic ash-fall horizon is absent. Notably, the inertinite and liptinite content of Unit 4 at Abbot Mountain, Venter's Bridge and Ulysses is significantly higher than at localities further to the south-west (Fig. 8).

Interpretation: The occurrence of normal grading within the ash-fall deposit and the presence of transported carbonaceous material indicates deposition in a subaqueous setting (Greb et al., 1999a), which explains its consistent preserva- 
A SW
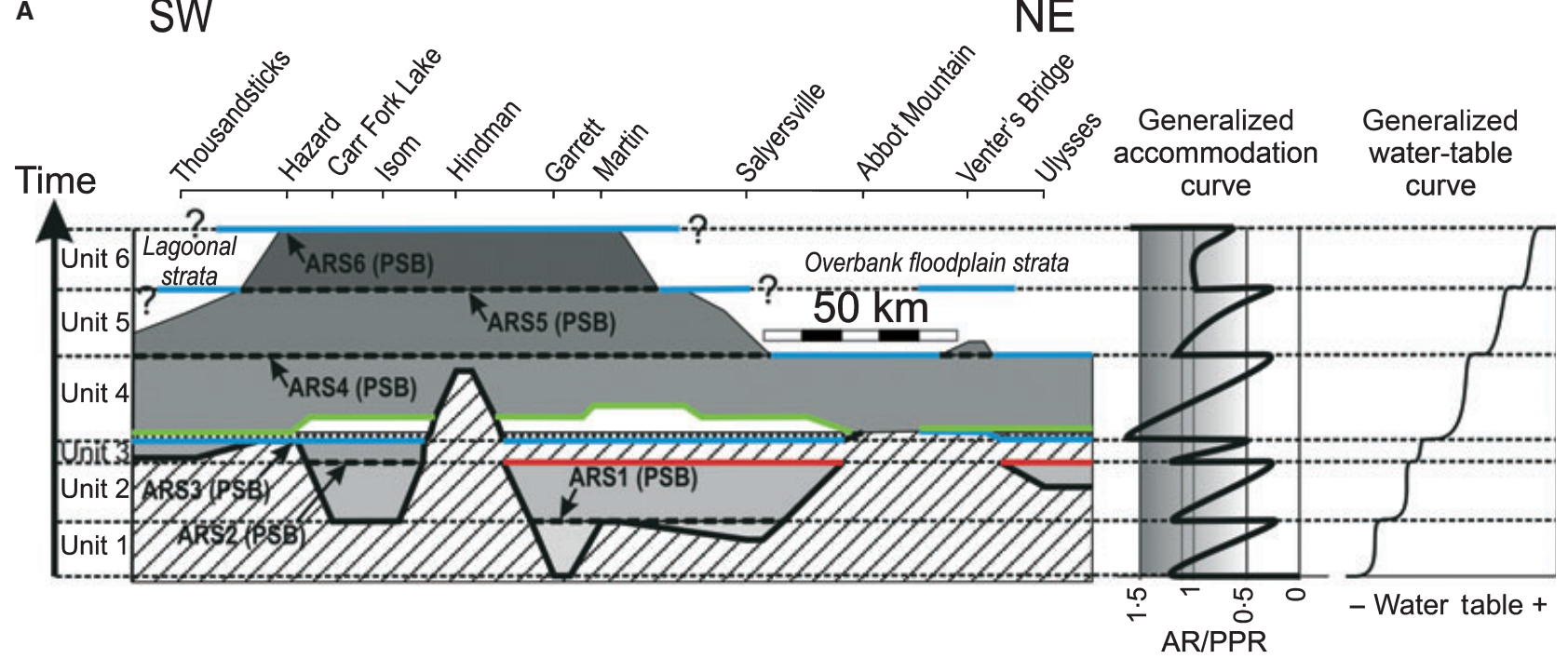

B SW
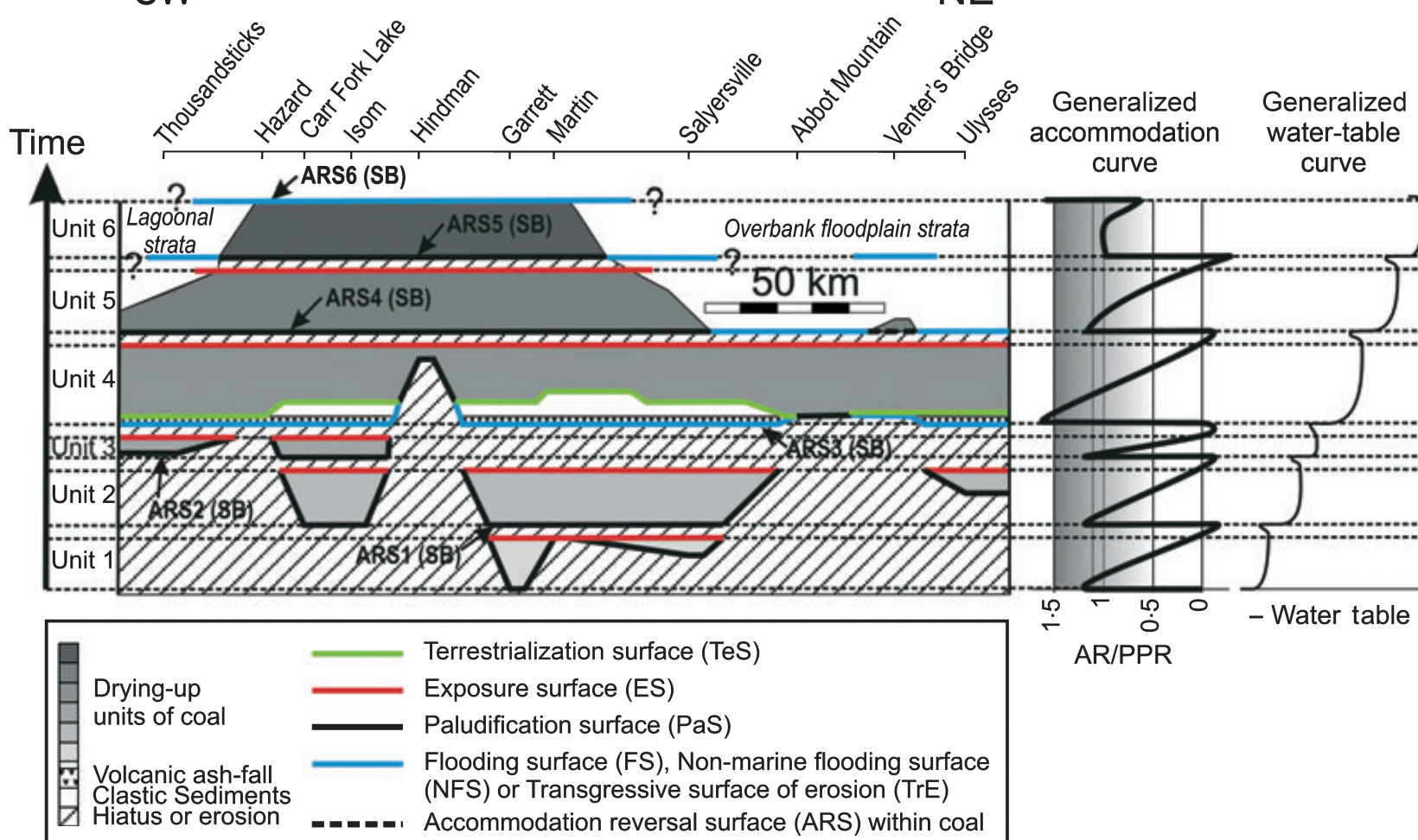

Fig. 9. Alternative sequence stratigraphic interpretations of the Fire Clay coal along with a generalized accommodation curve for the duration of the Fire Clay coal derived from trends identified in all 11 sections. (A) Schematic chronostratigraphic chart showing the spatial and temporal correlation of coal Units 1 to 6, and interpreted sequence stratigraphic surfaces. This model assumes that Units 1 to 6 were deposited during decreasing accommodation associated with a slowing rate of water-table rise, and are analogous to parasequences. (B) Schematic chronostratigraphic chart showing the spatial and temporal correlation of coal Units 1 to 6, and interpreted sequence stratigraphic surfaces. This model assumes that Units 1 to 6 were deposited during decreasing accommodation associated with a slowing rate of water-table rise, stillstand or falling water table. Units 1 to 6 are analogous to sequences. The line of section is illustrated in Fig. 4B. AR/PPR, accommodation rate/peat production rate.

tion over such a large area. Furthermore, the gradational contact of the ash-fall horizon with overlying clastic sediments and coal implies subaqueous transport and re-working of the volcanic material after settling from aeolian suspension. The sharp base of the deposit and the 
absence of protruding tree stumps from the underlying coal into the ash-fall horizon imply that Unit 4 was deposited following a depositional hiatus (Greb et al., 1999a). The widespread distribution of coal in the upper part of Unit 4 records a period of regional peat accumulation. Locally high detrital mineral content and the presence of pyrite indicate that the mire was morphologically planar and subject to periodic inundation by waters which were possibly brackish. Following the deposition of the ash-fall, peat accumulation was re-initiated by the process of terrestrialization during decreasing accommodation. South-west of Salyersville, the uppermost part of Unit 4 is interpreted as recording a period of widespread drying and oxidation of the peat surface, accompanied by significant biomassloss. Unit 4 therefore represents a drying-up succession (Fig. 9). The difficulty in correlating petrographic trends in Unit 4 at the Abbot Mountain, Venter's Bridge and Ulysses localities may result from autocyclic or localized variation in depositional conditions in the mire overprinting regional trends. Abbot Mountain, Venter's Bridge and Ulysses are located north of a basement structure (the Irvine-Paints Creek Fault system) thought to have been active at the time of accumulation of the Upper Breathitt Group (Greb et al., 2002a). To the north of this structure, Westphalian clastic strata and coal seams (including the Fire Clay coal; Fig. 8) thin significantly (Greb et al., 2002a) indicating that this was an area of reduced tectonic accommodation. The high inertinite and liptinite content of Unit 4, and the Fire Clay coal as a whole at Abbot Mountain, Venter's Bridge and Ulysses supports this interpretation. Analysis of petrographic trends at Hindman, Abbot Mountain and Venter's Bridge suggests that the bottom portion of Unit 4 is absent, whereas at Garrett the upper portion of Unit 4 appears to have been removed by erosional truncation during incision by younger fluvial deposits (Figs 8 and 9).

\section{Unit 5}

Description: Unit 5 is found at localities southwest of Salyersville, and as an outlier at Venter's Bridge (Fig. 8). It overlies Unit 4 and is up to $0.35 \mathrm{~m}$ thick. At Garrett and Salyersville, the occurrence of an incised valley-fill above Unit 4, suggests that Unit 5 may have been removed erosionally. At Thousandsticks and Venter's Bridge, Unit 5 forms the upper unit of the Fire Clay coal, and is overlain sharply by a succession of heterolithic lagoonal, bay-fill or floodplain overbank strata. Petrographically, it is dominated by vitrinite $(74.5 \%)$, and characterized by low detrital mineral content (5.0\%; Table 4). The unit is laterally variable, with central portions being thick and containing 2 to $4 \%$ clastic material, whereas at Thousandsticks and Venter's Bridge the unit is thinner and contains higher proportions of detrital minerals $(7 \cdot 8 \%$ and $13 \cdot 1 \%$ respectively). Vertical trends through Unit 5 show consistently high vitrinite concentrations. Approximately $0.05 \mathrm{~m}$ from the top of the unit, a major (but gradational) decrease in vitrinite is observed. This trend is accompanied by increases in liptinite and detrital mineral concentrations. Macroscopically, the contact of Unit 5 with overlying Unit 6 appears gradational in places (Fig. 8) but close inspection of polished coal blocks that cross this bounding surface (Fig. 10) reveal that the contact is sharp.

Interpretation: The low detrital mineral content of Unit 5 in the central part of the study area indicates almost complete exclusion of clastic sedimentation. Possible reasons for this are that: (i) peat was deposited in a raised, ombrotrophic mire, above the level of fluvial or marine inundation (Eble \& Grady, 1990; Eble et al., 1994); (ii) the development of peat became so widespread that external parts of the mire acted as buffers to regional siliciclastic input; or (iii) regional or local sources of clastic sediment supply became depleted at this time. The less widespread distribution of Unit 5 relative to Unit 4 favours the first hypothesis. At Thousandsticks and Venter's Bridge, the moderate to high detrital mineral content implies that at least a portion of the peat in Unit 5 was deposited in planar, rheotrophic conditions. The high vitrinite trend maintained upwards through Unit 5 indicates that peat accumulated during a period of time where peat growth could keep up with the rate of accommodation creation. Consistently low inertinite and liptinite concentrations indicate that oxidation was limited and that the preservation potential of peat was high. However, the decrease in vitrinite and increase in inertinite, liptinite and detrital minerals observed towards the top of this unit represent an increase in oxidation and biomassloss as a result of decreasing accommodation. On this basis, Unit 5 represents a net drying-up succession (Fig. 9).

\section{Unit 6}

Description: Unit 6 is restricted to Hazard, Carr Fork Lake, Isom, Hindman and Martin, where it overlies Unit 5 (Fig. 8). It displays considerable 


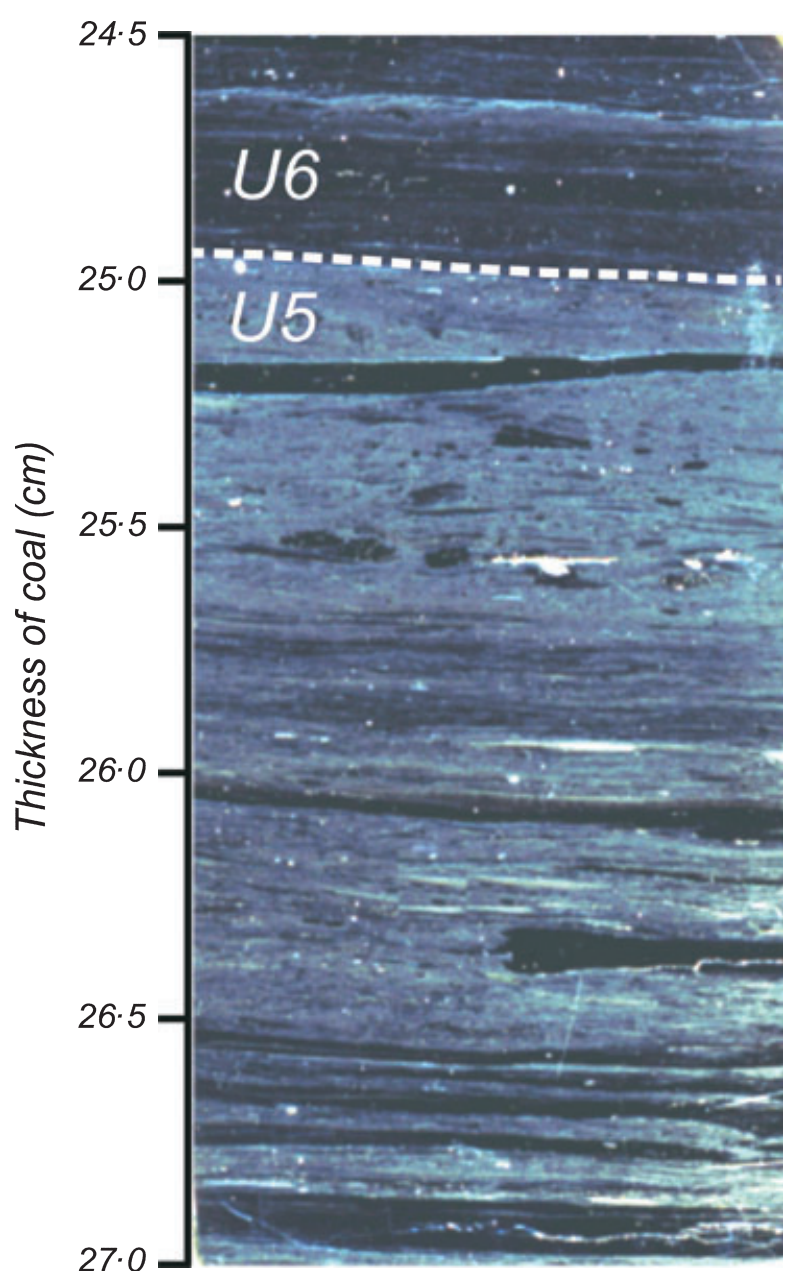

Fig. 10. Polished surface of a coal sample from Carr Fork Lake, showing the macroscopic expression of a sequence boundary or parasequence boundary. The top of Unit 5, seen in this photograph, shows a gradational drying-up trend. There is an upward loss in primary lamination, and an upward gain in disseminated inertinite (inertodetrinite), liptinite and detrital minerals (all appearing pale and dull) at the expense of structured vitrinite (telovitrinite; bright dark bands). There is a sharp contact between Units 5 and 6, marked by an abrupt increase in vitrinite, and the return of primary (depositional) lamination. This contact is traceable over at least $100 \mathrm{~km}$.

thickness variability $(0 \cdot 04$ to $0 \cdot 3 \mathrm{~m})$, which may be due to erosional truncation of the upper part of the Fire Clay coal at several localities. At Carr Fork Lake, where Unit 6 is not overlain by incised valley-fill sediments, the coal has a sharp contact with a coarsening-upward succession of heterolithic overbank strata. Like Unit 5 , this unit is also characterized by low detrital mineral content $(6.9 \%)$, but shows a marked increase in liptinite $(13 \cdot 0 \%)$ and inertinite $(19 \cdot 7 \%)$ content and lower vitrinite $(60 \cdot 4 \%)$ relative to Unit 5 (Table 4$)$. At
Hazard, where Unit 6 is thickest, it shows an initial upward increase in vitrinite accompanied by decreasing-upward inertinite and liptinite. The top $0 \cdot 1 \mathrm{~m}$ of Unit 6 , however, displays a decrease in vitrinite, and a return to higher inertinite, inertodetrinite and liptinite.

Interpretation: The low detrital mineral content of Unit 6 is indicative of raised ombrotrophic mire conditions and/or a lack of clastic supply. The vertical compositional trends in Unit 6 show an initial wetting-up trend at Hazard and Carr Fork Lake. At Hazard, this is followed by a drying-up trend (Fig. 9), but there are uncertainties in this interpretation due to non-deposition or erosion of all or part of Unit 6 at other localities.

In summary, the Fire Clay coal is composed of six units of coal and clastic sediment that are separated vertically by widespread petrographic discontinuities. Analysis of maceral and mineral assemblages within the six units, indicate that they represent differing environments of accumulation, including: (i) small (kilometre scale) disconnected planar rheotrophic mires; (ii) regionally developed planar theotrophic mires (hundreds of $\mathrm{km}^{2}$ ) that developed into raised, ombrotrophic mires in places; and (iii) lacustrine, lagoonal or bay environments. All six units are interpreted as drying-up successions, formed in response to decreasing accommodation. Interpretation of the depositional and accommodation history of the Fire Clay coal is based on analysis of the stacking-pattern of these six units and their relationship with the overlying and underlying clastic facies.

\section{DISCUSSION}

\section{Sequence stratigraphic context of the Fire Clay coal}

The deeply rooted claystone that commonly underlies the Fire Clay coal has previously been interpreted as representing an interfluve palaeosol, which correlates laterally with an incised valley complex. The top of this palaeosol was therefore interpreted as a sequence boundary (Aitken \& Flint, 1995, 1996). The sharp nature of the contact between the Fire Clay coal and the palaeosol is consistent with this interpretation, as it implies that clastic sedimentation was not gradually replaced with peat accumulation. The base of the coal is therefore interpreted as a hiatal paludification surface (PaS; Fig. 9), as it defines the surface of transition from subaerial exposure 
to positive accommodation and peat accumulation during water-table (base-level) rise; this is the terrestrial equivalent of a transgressive surface. The unit bounding surfaces within the Fire Clay coal (Fig. 9) provide time-lines which indicate that the process of paludification was diachronous, initiating first at Garrett (Unit 1) and last at Hindman (Unit 4). Using the top of the volcanic ash-fall horizon within the Fire Clay coal as a horizontal datum, and assuming a peat to coal compaction ratio of 10:1 (Ryer \& Langer, 1980), the base of the coal may represent a pre-existing surface which had up to $10 \mathrm{~m}$ of topographic relief. This finding is consistent with the observations of the present study at outcrop scale, where the elevations of (post-compaction) Breathitt Group coal seams commonly rise and fall by up to $5 \mathrm{~m}$. Peat initially accumulated in small, disconnected, planar mires at the bases of topographic hollows (Unit 1; Fig. 9; Greb et al., 1999a) that aggraded and onlapped against the topographic surface and gradually became less confined (Units 2 and 3; Fig. 9). The process of onlap culminated in the healing of topography, the development of a uniform, low gradient plain and deposition of regionally widespread, unconfined planar and raised mires (Units 4 to 6; Fig. 9; Greb et al., 1999a).

At the Abbot Mountain sampling locality, the Fire Clay coal overlies an incised valley-fill. Here, the sequence boundary is interpreted as lying at the base of the incised valley-fill and not directly beneath the coal seam. A palaeosol is present beneath the coal but is much thinner than at other localities. The Fire Clay coal, nevertheless, has a sharp contact with the underlying palaeosol $(\mathrm{PaS})$, implying some degree of hiatus before the initiation of peat accumulation.

Where overlying incised valleys do not cut down to the top of the Fire Clay coal (i.e. Thousandsticks, Carr Fork Lake, Abbot Mountain, Venter's Bridge and Ulysses; Fig. 8), Units 4, 5 or 6 are overlain sharply by coarsening-up successions of heterolithic strata known to contain rare marine to fresh water fauna (Cobb et al., 1981; Chesnut, 1991), interpreted as lagoonal, bay-fill and/or floodplain deposits. The upper boundary of the coal is interpreted as a flooding surface (FS) or non-marine flooding surface (NFS; Fig. 9), which represents an abrupt increase in accommodation and the termination of peat accumulation. Transgression of the Fire Clay coal was progressive, initiating first at Ulysses and Abbot Mountain at the time of accumulation of peat Unit 5, and culminating in the burial of
Unit 6 at Hazard and Carr Fork Lake (Fig. 9). Alternatively, the relationship of the coal with the overlying clastic strata could be explained by transgressive erosion (TrE; Fig. 9) removing portions of the peat. This interpretation would imply that the complete accommodation history of the Fire Clay coal may not be preserved.

The relationship of the Fire Clay coal with the underlying and overlying clastic facies implies that it accumulated during a period of increasing accommodation rate, and represents a transition from subaerial exposure to marine or non-marine inundation. The paludification surface may be the up-dip equivalent of a marine transgressive surface in more distal parts of the basin. Investigations carried out during this study, along with the reinterpretation of the work of other authors (Chesnut, 1991; Aitken \& Flint, 1994, 1995), indicates that this may be a common feature of most major coals or coal zones in the Breathitt Group.

\section{Identification and implication of intra-coal seam key surfaces}

Within the Fire Clay coal petrographic trends do not reflect a single trend of increasing accommodation. Units 1 to 6 represent a succession of higher-frequency, asymmetric cycles, each characterized by a drying-up succession that accumulated during gradually decreasing accommodation, and bounded by surfaces that delineate an abrupt shift in coal facies representing a rapid increase in accommodation (Figs 8 to 10). The unit bounding surfaces represent an amalgamated pair of accommodation reversal surfaces (ARS), such that the wetting-up component of the cycles was temporally a relatively instantaneous event and therefore is not represented by any thickness of coal (Fig. 9). The asymmetrical character of these accommodation cycles can be generated by superimposing high-frequency symmetrical sinusoidal water-table (base-level) fluctuations on a gradual, steady background trend of water-table rise (Fig. 9). This interaction would generate episodes of rapid water-table rise when accommodation increased rapidly. Because of the background water-table rise, the fall component of each high-frequency cycle would be suppressed, resulting in periods of slowing rate of rise (Fig. 9 A) to stillstand or minor fall (Fig. 9B) when the accommodation rate falls.

If decreasing accommodation was produced only by a slowing rate of water-table rise (i.e. Fig. 9A), each unit would be analogous to a 
parasequence (sensu Van Wagoner et al., 1988); this is because they would be similar to a relatively conformable sedimentary succession bounded by the terrestrial equivalent of a flooding surface, with only minor hiatus in accumulation indicated. If, however, there was a component of water-table fall during decreasing accommodation (i.e. Fig. 9B), then an episode of exposure and deflation of the peat surface would be implied, before peat accumulation re-initiated to form the base of the following unit. In this respect, each unit would be analogous to a sequence (sensu Van Wagoner et al., 1988) in that they would be bounded by a surface across which there is evidence for subaerial exposure, with significant hiatus in accumulation indicated. These sequence stratigraphic definitions hold true at all frequencies, durations or stratigraphic thicknesses. The high concentrations of resistant peat components (i.e. liptinite and detrital minerals) at the tops of the drying-up successions (Fig. 8C and D) support the notion of a decreasing rate of water-table rise and peat accumulation, and may indicate significant oxidative removal of woody peat resulting from subaerial exposure during lowered water table. It is difficult to demonstrate conclusively whether the units of the Fire Clay coal represent parasequences bounded by non-hiatal parasequence boundaries or sequences bounded by hiatal sequence boundaries. However, the fact that each unit represents markedly different mire conditions with different aerial distributions supports the notion of temporal disconnection between each unit (Greb et al., 1999a, 2002b). The photograph shown in Figure 10 displays the typical macroscopic expression of unit bounding surfaces in the Fire Clay coal. Dull coal, with reworked primary lamination directly underlies the surface, and bright, laminated coal overlies it. Surfaces remarkably similar to the unit bounding surfaces of the Fire Clay coal have been described by Diessel (1998) in the Permian Wynn-Bayswater seam of the Sydney Basin, and by Davies et al. (2006) in the Cretaceous Sunnyside coal of the Western Interior Basin. In both cases, the surfaces could be correlated laterally to a sequence boundary developed in time-equivalent clastic strata. The high inertinite layers developed at the tops of the drying-up successions in the Fire Clay coal (Fig. 8B) are similar to the 'oxidized organic parting' of Shearer et al. (1994), who interpreted these as hiatal bounding surfaces between separate, genetic 'peat bodies'. These are also similar to oxidized layers described from the surfaces of Holocene mires, which have deflated and ceased accumulating peat as the result of increased microbial degradation during lowered water tables (Prokopovich, 1985; Esterle \& Ferm, 1994; Cohen \& Stack, 1996; Moore et al., 1996).

Large et al. (2003) argued that no significant hiatus occurred within the Palaeocene Wyodak coal of the Powder River Basin, on the basis that no major erosion surfaces have been noted within the coal. An absence of erosion surfaces within a coal does not provide evidence for the absence of hiatus or water-table fall. The style of reworking during subaerial exposure in a mire, which is characterized by passive microbial degradation of the peat surface above the water table, results in a homogeneous and gradual planation of the peat surface, rather than active, mechanical incision. Peat, made-up of flexible, intertwined mats of plant matter, is a resistant material, able to endure relatively high erosive stresses (McCabe, 1984). Hence hiatal, subaerial exposure surfaces within coals would be more analogous to the relatively flat deflation or karst surfaces which form following base-level fall in aeolian and carbonate environments, respectively.

\section{Periodicity of water-table cycles}

The maximum duration of peat accumulation associated with the Fire Clay coal is constrained by the duration of the high-order sequence (coalclastic cycle of Chesnut, 1992; Fig. 5) within which the Fire Clay coal is part of the transgressive systems tract. Based on the biostratigraphic data of Riley \& Turner (1995) and the identification of marine zones (Chesnut, 1991; Fig. 5) in the upper Breathitt Group, the Westphalian B succession comprises 13 such sequences. Applying the time scale of Menning et al. (2006; Fig. 5), an average sequence duration of $\mathrm{ca} 190 \mathrm{ka}$ (fourthorder cf. Mitchum \& Van Wagoner, 1991) is inferred, which is approximately double the $c a$ $100 \mathrm{ka}$ sequence duration calculated by Greb et al. (2008) using the U-Pb absolute age dates of tonsteins of Lyons et al. $(1997,2006)$ from the Fire Clay coal (Hyden Formation) and Upper Banner Coal (Grundy Formation; Fig. 5). Assuming that the Fire Clay coal accumulated during transgression of a $\mathrm{Ca} 190$ ka duration sequence, then the maximum amount of time represented by the coal is more likely to be around $100 \mathrm{ka}$. Duration minima can be calculated based on estimated peat to coal compaction ratios of around 10:1 and peat accumulation rates of 1 to $5 \mathrm{~mm}$ year $^{-1}$, using the Holocene record (Diessel et al., 2000). This observation indicates that the 
Fire Clay coal, where it is $c a 1.5 \mathrm{~m}$ thick (for example, Carr Fork Lake), could represent 3 to 15 ka of accumulation history. These calculations do not take into account evidence for slowed rates of peat accumulation, hiatus or erosion, which may be 'locked-up' within the Fire Clay coal, and therefore the time represented by the coal is likely to be considerably longer than 3 to $15 \mathrm{ka}$. On this basis, the amount of time represented by the coal is between 3 and $100 \mathrm{ka}$. Modern low-latitude peatlands are known to have begun accumulating as long ago as ca $33 \mathrm{ka}$ BP (Page et al., 2004), which is within the range of duration estimated for the Fire Clay coal. Radiocarbon profiles of these peats typically reveal that accumulation was punctuated by hiatuses up to $10 \mathrm{ka}$ in duration (Ledru et al., 1998; Anshari et al., 2001; Page et al., 2004). The six units (asymmetrical water-table cycles) recorded within the Fire Clay coal may therefore represent Milankovitch to sub-Milankovitch base-level fluctuation periodicities of 0.5 to $17 \mathrm{ka}$. Interpretations of the duration of time represented by the Fire Clay coal must, however, be tempered by acknowledgement of the wide range of peat to coal compaction ratios cited in the literature (from 1·2:1 to 30:1; Ryer \& Langer, 1980), and the untested uniformitarian approach to peat accumulation rates at a time when atmospheric composition and botany were considerably different from the Holocene (Berner \& Canfield, 1989; DiMichele \& Phillips, 1994).

\section{Driving mechanism for water-table cyclicity}

The recognition of similar fourth-order, coalbearing depositional sequences and the correlation of the same marine bands in the Central Appalachian Basin and North-west Europe (Riley \& Turner, 1995; Hampson et al., 1997; Davies et al., 1999) indicate a continent-scale mechanism for their formation. The short duration of the sequences is consistent with high-frequency, high-magnitude (20 to $100 \mathrm{~m}$; Rygel et al., 2008) eustatic sea-level fluctuations driven by changes in the volume of the Gondwanan ice-cap (Chesnut, 1994; Greb et al., 2008). In paralic settings, the ground water table is hydrologically connected to the sea, and rises landward in conformity with the optimum graded profile of a mature stream (Diessel, 1992). Studies of modern paralic environments have shown that changes in relative sea-level can influence ground water tables up to $150 \mathrm{~km}$ inland (Tornqvist, 1993). Davies et al. (2006) in their study of the Cretaceous Sunnyside coal, demonstrated that relative sea- level was the dominant control on accommodation in peat $30 \mathrm{~km}$ up-dip of the palaeoshoreline. Therefore, it is possible that the cyclic water-table fluctuations recorded within the Fire Clay coal can be attributed to high-frequency fluctuations in sea-level, even without marine incursions recorded as clastic split.

However, this study documents regional baselevel fluctuations over a greater distance $(>100 \mathrm{~km})$ in a mire that was considerably larger (37 $000 \mathrm{~km}^{2}$; Outerbridge, 2003) compared with previous and similar sequence stratigraphic studies of coal seams, where fluctuations in base level have been linked to adjacent sea-level change (Diessel, 1992, 1998; Banerjee et al., 1996; Petersen \& Andsbjerg, 1996; Petersen et al., 1998; Diessel et al., 2000; Holz et al., 2002; Wadsworth et al., 2002, 2003; Davies et al., 2005, 2006). Since the relative influence of eustacy and climate on base level vary with distance from the shoreline (Shanley \& McCabe, 1994) landward portions of the mire may have been more removed from the direct influence of sea-level change. Water-table fluctuations in parts of the Fire Clay coal interpreted as partly of domed, ombrotrophic origin (for example, Unit 5) are more likely to preserve a climate record (Eble et al., 1994) as, by definition, ombrotrophy requires hydrological isolation from the surrounding water table. Present-day coastal peatlands of equatorial South-east Asia, cited as analogous systems to mires of the Euramerican Coal province (Cecil, 1990; Esterle \& Ferm, 1994; Staub \& Esterle, 1994) can extend inland for more than $200 \mathrm{~km}$ from the coast, and are dominantly ombrotrophic systems in which water and nutrient supply are derived from precipitation alone (Page et al., 2004). For this reason, these systems are generally considered to preserve only a record of climatically induced base-level fluctuations (Wüst \& Bustin, 2004; Wüst et al., 2008).

Given the available evidence, it is not possible to assign the base-level fluctuations to either relative sea-level or climatic changes. This study recognizes that both are a function of global insolation changes, which may be related to orbital forcing, and in paralic settings the level of the water table may be a function of both.

\section{CONCLUSIONS}

The Fire Clay coal, in common with most major coal seams in the upper Breathitt Group of the Central Appalachian Basin, accumulated during the late lowstand systems tract or early transgres- 
sive systems tract of a fourth-order (ca $190 \mathrm{ka}$ frequency) sequence, when peat accumulation could keep up with eustatically driven base-level rise, and clastic sedimentation was confined largely to the margins of the basin. Peat accumulation was initiated through the process of paludification, above incised valley-fills and on adjacent subaerially exposed interfluves; this is the terrestrial expression of a marine transgressive surface. The identification of time-lines within the Fire Clay coal demonstrates that paludification, and therefore transgression, was diachronous. Peat accumulated first in topographic hollows, aggraded and progressively onlapped against a topographic surface in response to base-level rise. The seam is overlain by a regional marine to non-marine flooding surface which resulted from the rate of accommodation creation progressively outpacing the rate of peat production. Marine to non-marine transgression of the Fire Clay mires may have eroded and reworked the peat surface.

Within the Fire Clay coal, six drying-up successions (units) of coal correspond to six highfrequency accommodation cycles. Each unit is characterized by a basal bounding surface, which delineates an episode of abrupt increase in accommodation, overlain by a drying-up succession. Overall, these units accumulated during gradually decreasing accommodation. Increasing concentrations of intertinite, inertodetrinite and resistant peat components (liptinite and detrital minerals) in the drying-up successions indicate that increasing oxidation was accompanied by increased reworking and decreasing peat accumulation rates associated with a slowed rate of water-table rise. High concentrations of liptinite and detrital minerals at the tops of drying-up successions may represent a residue of peat remaining from a phase of significant exposure and oxidative removal of plant material resulting from a falling water table. The fact that each unit (accommodation cycle) represents markedly different mire conditions with different aerial distributions, suggests temporal disconnection between each unit, and that considerable time may be 'locked-up' in the unit bounding surfaces. The asymmetrical character of the base-level fluctuations can be explained by superimposing high-frequency, symmetrical sinusoidal sea-level or climatically driven water-table fluctuations on a background sea-level driven fourth-order base-level rise.

Recognition that the rate of peat accumulation may respond to high-frequency water-table fluctuations has implications for studies that implicitly or explicitly assume coal seams to represent continuous, time-invariant records of base-level fluctuations or palaeoecological change (White et al., 1994; Petersen \& Andsbjerg, 1996; Petersen et al., 1998; Large et al., 2003, 2004; Kvale et al., 2004; Briggs et al., 2007). Calculating the duration of time represented by coal seams by assuming a continuous peat accumulation rate, and tuning non-linear peat and coal records to calibrated time scales may provide misleading results (Holdgate et al., 2007). The fact that coal seams may be composed of multiple, stacked mires which accumulated under different conditions with different overall compositions and aerial distributions has implications for predicting whole-seam quality and thickness beyond available data points.

\section{ACKNOWLEDGEMENTS}

The funding for this research was provided by the United Kingdom Natural Environment Research Council, Rio Tinto Technology, the IAS Postgraduate Grant Scheme and the British Sedimentological Research Group Steve Farrell Memorial Fund. The authors acknowledge Steve Greb (Kentucky Geological Survey) for his help with field logistics and discussion of the work, and Rory O'Hara Murray and John Cummings (University of Liverpool) for their field assistance. Frank van den Belt (TNO/Geological Survey, The Netherlands) and Cortland Eble (Kentucky Geological Survey) are thanked for their thought provoking and constructive reviews of the manuscript.

\section{REFERENCES}

Aitken, J.F. and Flint, S. (1994) High-frequency sequences and the nature of incised-valley fills in fluvial systems on the Breathitt Group (Pennsylvanian), Appalachian foreland basin, eastern Kentucky. In: Incised Valley Systems: Origin and Sedimentary Sequences (Eds R. Dalrymple, R. Boyd and B.A. Zaitlin), SEPM Spec. Publ., 51, 353-368.

Aitken, J.F. and Flint, S.S. (1995) The application of highresolution sequence stratigraphy to fluvial systems: a case study from the Upper Carboniferous Breathitt Group, eastern Kentucky, USA. Sedimentology, 42, 3-30.

Aitken, J.F. and Flint, S.S. (1996) Variable expressions of interfluvial sequence boundaries in the Breathitt Group (Pennsylvanian), eastern Kentucky, USA. Geol. Soc. London Spec. Publ., 104, 193-206.

Anshari, G., Kershaw, P.A. and van der Kaars, S. (2001) A Late Pleistocene and Holocene pollen and charcoal record from peat swamp forest, Lake Sentarum Wildlife Reserve, 
West Kalimantan, Indonesia. Palaeogeogr. Palaeoclimatol. Palaeoecol., 171, 213-228.

Australian Standard AS 2856.2-1998 (1998) Coal Petrography. Part 2: Maceral Analysis. Standards Association of Australia, North Sydney, $32 \mathrm{pp}$.

Banerjee, I., Kalkreuth, W. and Davies, E.H. (1996) Coal seam splits and transgressive-regressive coal couplets: a key to stratigraphy of high-frequency sequences. Geology, 24, 1001-1004.

Berner, R.A. and Canfield, D.E. (1989) A new model for atmospheric oxygen over Phanerozoic time. Am. J. Sci., 289, 333-361.

Bohacs, K. and Suter, J. (1997) Sequence stratigraphic distribution of coaly rocks: fundamental controls and paralic examples. AAPG Bull., 81, 1612-1639.

Bohor, B.F. and Triplehorn, D.M. (1981) Volcanic origin of the flint clay parting in the Hazard No. 4 (Fire Clay) coal bed, southeastern Kentucky. In: Coal and Coal-Bearing Rocks of Eastern Kentucky, Annual Geological Society of America Coal Division Field Trip (Eds J.C. Cobb, D.R. Chesnut, N.C. Hester and J.C. Hower), Kentucky Geol. Surv., 11, 49-54.

Briggs, J., Large, D.J., Snape, C., Drage, T., Whittles, D., Cooper, M., Macquaker, J.H.S. and Spiro, B.F. (2007) Influence of climate and hydrology on carbon in an early Miocene peatland. Earth Planet. Sci. Lett., 253, 445-454.

Brown, K.E. and Cohen, A.D. (1995) Stratigraphic and micropetrographic occurrences of pyrite in sediments at the confluence of carbonate and peat-forming depositional systems, southern Florida, U.S.A. Org. Geochem., 22, 105-126.

Calder, J.H. (1991) Controls on Westphalian Peat Accumulation: The Springhill Coal Field, Nova Scotia. Dalhousie University, Halifax, NS, Canada.

Calder, J.H. and Gibling, M.R. (1994) The Euramerican Coal Province: controls on Late Paleozoic peat accumulation. Palaeogeogr. Palaeoclimatol. Palaeoecol., 106, 1-21.

Cameron, C.C., Esterle, J.S. and Palmer, C.A. (1989) The geology, botany and chemistry of selected peat-forming environments from temperate and tropical latitudes. Int. J. Coal Geol., 12, 105-156.

Cecil, C.B. (1990) Paleoclimate controls on stratigraphic repetition of chemical and siliciclastic rocks. Geology, 18, 533-536.

Chesnut, D.R. (1991) Paleontological Survey of the Pennsylvanian Rocks of the Eastern Kentucky Coal Field. Kentucky Geological Survey, Lexington, 71 pp.

Chesnut, D.R. (1992) Stratigraphic and structural framework of the Carboniferous rocks of the Central Appalachian Basin. Kentucky Geol. Surv. Ser. 11, 3, 42.

Chesnut, D.R. (1994) Eustatic and tectonic control of the lower and middle Pennsylvanian strata of the Central Appalachian Basin. In: Tectonic and Eustatic Controls on Sedimentary Cycles (Eds J.M. Dennison and F.R. Ettensohn), SEPM Concepts Sedimentol. Paleontol., 4, 25-34.

Clymo, R.S. (1983) Peat. In: Mires: Swamp, Bog, Fen and Moor (Ed. A.J.P. Gore), 4A, pp. 159-224. Elsevier, Amsterdam.

Clymo, R.S. (1987) Rainwater-fed peat as a precursor of coal. In: Coal and Coal-Bearing Strata: Recent Advances (Ed. A.C. Scott), Geol. Soc. London Spec. Publ., 32, 107-125.

Cobb, J.C., Chesnut, D.R., Hester, N.C. and Hower, J.C. (1981) Coal and Coal-Bearing Rocks of Eastern Kentucky. Kentucky Geological Survey, Lexington.

Cohen, A.D. and Stack, E.M. (1996) Some observations regarding the potential effects of doming of tropical peat deposits on the composition of coal beds. Int. J. Coal Geol., 29, 39-65.
Cohen, A.D., Spackman, W. and Raymond, R. Jr (1987) Interpreting the characteristics of coal seams from chemical, physical and petrographic studies of peat deposits. In: Coal and Coal-Bearing Strata: Recent Advances (Ed. A.C. Scott), Geol. Soc. London Spec. Publ., 32, 17-23.

Cross, T.A. (1988) Controls on coal distribution in transgressive-regressive cycles, Upper Cretaceous, Western Interior, U.S.A. In: Sea Level Changes - An Integrated Approach (Eds C.H. Wilgus, B.S. Hastings, C.G.S.C. Kendall, H.W. Posamentier, C.A. Ross and J.C. Van Wagoner), SEPM Spec. Publ., 42, 371-380.

Crowley, S.S., Dufek, D.A., Stanton, R.W. and Ryer, T.A. (1994) The effects of volcanic ash disturbances on a peatforming environment; environmental disruption and taphonomic consequences. Palaios, 9, 158-174.

Davies, S.J., Hampson, G.J., Flint, S.S. and Elliott, T. (1999) Continent-scale sequence stratigraphy of the Upper Carboniferous and its applications to reservoir prediction. In: Petroleum Geology of Northwest Europe: Proceedings of the 5th conference (Eds A.J. Fleet and S.A. Boldy), pp. 757-770. The Geological Society of London, Bath.

Davies, R., Howell, J., Boyd, R., Flint, S. and Diessel, C. (2005) Vertical and lateral variation in the petrography of the Upper Cretaceous Sunnyside coal of eastern Utah - implications for the recognition of high-resolution accommodation changes in paralic coal seams. Int. J. Coal Geol., 61, 13-33.

Davies, R., Howell, J., Boyd, R., Flint, S. and Diessel, C. (2006) High-resolution sequence-stratigraphic correlation between shallow-marine and terrestrial strata: examples from the Sunnyside Member of the Cretaceous Blackhawk Formation, Book Cliffs, eastern Utah. AAPG Bull., 90, 1121-1140.

Diessel, C. (1985) Macerals as coal facies indicators. In: 10th International Congress of Carboniferous Stratigraphy and Geology, Madrid, 3, pp. 367-373. Instituto Geologico y Minero de España, Madrid.

Diessel, C. (1986) On the correlation between coal facies and depositional environments. In: Advances in the Study of the Sydney Basin, 20th Newcastle Symposium Proceedings (Ed. C.F.K. Diessel), pp. 19-22. University of Newcastle, Australia.

Diessel, C. (1992) Coal-Bearing Depositional Systems. Springer-Verlag, Berlin, Germany.

Diessel, C. (1998) Sequence stratigraphy applied to coal seams: two case histories. In: Relative Role of Eustacy, Climate and Tectonism in Continental Rocks (Eds K.W. Shanley and P.J. McCabe), SEPM Spec. Publ., 59, 151-173.

Diessel, C. (2007) Utility of coal petrology for sequencestratigraphic analysis. Int. J. Coal Geol., 70, 3-34.

Diessel, C.F.K. and Gammidge, L. (1998) Isometamorphic variations in the reflectance and fluorescence of vitrinite-a key to depositional environment. Int. J. Coal Geol., 36, 167-222.

Diessel, C., Boyd, R., Wadsworth, J., Leckie, D. and Chalmers, G. (2000) On balanced and unbalanced accommodation/ peat accumulation ratios in the Cretaceous coals from Gates Formation, Western Canada, and their sequencestratigraphic significance. Int. J. Coal Geol., 43, 143-186.

DiMichele, W.A. and Phillips, T.L. (1994) Paleobotanical and paleoecological constraints on models of peat formation in the Late Carboniferous of Euramerica. Palaeogeogr. Palaeoclimatol. Palaeoecol., 106, 39-90.

Eble, C.F. and Grady, W.C. (1990) Paleoecological interpretation of a middle Pennsylvanian coal bed in the central Appalachian basin, U.S.A. Int. J. Coal Geol., 16, 255-286.

Eble, C.F., Hower, J.C. and Andrews, W.M. Jr (1994) Paleoecology of the Fire Clay coal bed in a portion of the Eastern 
Kentucky Coal Field. Palaeogeogr. Palaeoclimatol. Palaeoecol., 106, 287-305.

Englund, K.J. and Thomas, R.E. (1990) Late Paleozoic depositional trends in the central Appalachian Basin. Bull. US Geol. Surv., 1839, F1-F19.

Esterle, J.S. and Ferm, J.C. (1994) Spatial variability in modern tropical peat deposits from Sarawak, Malaysia and Sumatra, Indonesia: analogues for coal. Int. J. Coal Geol., 26, 1-41.

Greb, S.F., Eble, C.F. and Hower, J.C. (1999a) Depositional history of the Fire Clay coal bed (Late Duckmantian), Eastern Kentucky, USA. Int. J. Coal Geol., 40, 255-280.

Greb, S.F., Hiett, J.K., Weisenfluh, G.A., Andrews, R.E. and Sergent, R.E. (1999b) Geology of the Fire Clay Coal in part of the eastern Kentucky coal field. Kentucky Geological Survey, Lexington.

Greb, S.F., Weisenfluh, G.A., Andrews, R.E., Hiett, J.K., Cobb, J.C. and Sergent, R.E. (1999c) Available resources of the Fire Clay Coal in oart of the eastern Kentucky coal field. Kentucky Geological Survey, Lexington.

Greb, S.F., Eble, C.F. and Chesnut, D.R. (2002a) Comparison of the Eastern and Western Kentucky coal fields (Pennsylvanian), USA - why are coal distribution patterns and sulfur contents so different in these coal fields? Int. J. Coal Geol., 50, 89-118.

Greb, S.F., Eble, C.F., Hower, J.C. and Andrews, W.M. (2002b) Multiple-bench architecture and interpretations of original mire phases - examples from the Middle Pennsylvanian of the Central Appalachian Basin, USA. Int. J. Coal Geol., 49, 147-175.

Greb, S.F., Pashin, J.C., Martino, R.L. and Eble, C.F. (2008) Appalachian sedimentary cycles during the Pennsylvanian: changing influences of sea-level, climate and tectonics. In: Resolving the late Paleozoic Ice Age in Time and Space (Eds C.R. Fielding, T.D. Frank and J.L. Isbell), Geol. Soc. Am. Spec. Pap., 441, 235-248.

Hacquebard, P.A. and Donaldson, J.R. (1969) Carboniferous coal deposition associated with flood-plain and limnic environments in Nova Scotia. In: Environments of Coal Deposition (Eds E.C. Dapples and M.E. Hopkins), Special Paper, 114, pp. 143-191. Geological Society of America, Boulder, CO.

Hampson, G.J., Elliott, T. and Davies, S.J. (1997) The application of sequence stratigraphy to Upper Carboniferous fluvio-deltaic strata of the onshore UK and Ireland: implications for the southern North Sea. J. Geol. Soc., 154, 719733.

Hess, J.C. and Lippolt, H.J. (1986) ${ }^{40} \mathrm{Ar} /{ }^{39} \mathrm{Ar}$ ages of tonstein and tuff sanidines - new calibration points for the improvement of Upper Carboniferous time scale. Chem. Geol., 59, 143-154.

Holdgate, G.R., Cartwright, I., Blackburn, D.T., Wallace, M.W., Gallagher, S.J., Wagstaff, B.E. and Chung, L. (2007) The Middle Miocene Yallourn coal seam - the last coal in Australia. Int. J. Coal Geol., 70, 95-115.

Holz, M., Kalkreuth, W. and Banerjee, I. (2002) Sequence stratigraphy of paralic coal-bearing strata: an overview. Int. J. Coal Geol., 48, 147-179.

Kosters, E.C. and Suter, J.R. (1993) Facies relationships and systems tracts in the late Holocene Mississippi Delta Plain. J. Sed. Res., 63, 727-733.

Kvale, E.P., Mastalerz, M., Furer, W.E., Rexroad, C.B. and Eble, C.F. (2004) Atokan and early Desmoinesian coalbearing parasequences in Indiana, USA. In: Sequence Stratigraphy, Paleoclimate and Tectonics of Coal-Bearing Strata
(Eds J.C. Pashin and R.A. Gastaldo), Am. Assoc. Petrol. Geol. Stud. Geol., 51, 71-88.

Large, D.J., Jones, T.F., Somerfield, C., Gorringe, M.C., Spiro, B., Macquaker, J.H.S. and Atkin, B.P. (2003) High-resolution terrestrial record of orbital climate forcing in coal. Geology, 31, 303-306.

Large, D.J., Jones, T.F., Briggs, J., Macquaker, J.H.S. and Spiro, B.F. (2004) Orbital tuning and correlation of 1.7 m.y. of continuous carbon storage in an early Miocene peatland. Geology, 32, 873-876.

Ledru, M.-P., Bertaux, J., Sifeddine, A. and Suguio, K. (1998) Absence of last glacial maximum records in lowland tropical forests. Quatern. Res., 49, 233-237.

Lyons, P.C., Outerbridge, W.F., Triplehorn, D.M., Howard, T.E., Congdon, R.D., Capiro, M., Hess, J.C. and Nash, W.P. (1992) An Appalachian isochron: a kaolinized Carboniferous air-fall volcanic-ash deposit (tonstein). Geol. Soc. Am. Bull., 104, 1515-1527.

Lyons, P.C., Krogh, T., Kwok, Y. and Zodrow, E.L. (1997) U-Pb age of zircon crystals from the upper Banner tonstein (Middle Pennsylvanian), Virginia; absolute age of the Lower Pennsylvanian-Middle Pennsylvanian boundary and depositional rates for the Middle Pennsylvanian, central Appalachian Basin. In: XIII International Congress on Carboniferous and Permian (Eds M. Podemski, S. DybovaJachowicz, K. Jaworowski, J. Jureczka and R. Wagner), 157, pp. 159-166. Prace Panstwowego Instytutu Geologicznego, Warsaw.

Lyons, P.C., Krogh, T.E., Kwok, Y.Y., Davis, D.W., Outerbridge, W.F. and Evans, J.H.T. (2006) Radiometric ages of the Fire Clay tonstein [Pennsylvanian (Upper Carboniferous), Westphalian, Duckmantian]: a comparison of U-Pb zircon single-crystal ages and 40Ar/39Ar sanidine singlecrystal plateau ages. Int. J. Coal Geol., 67, 259-266.

Martino, R.L. (1996) Stratigraphy and depositional environments of the Kanawha Formation (Middle Pennsylvanian), southern West Virginia, U.S.A. Int. J. Coal Geol., 31, 217-248.

McCabe, P.J. (1984) Depositional environments of coal and coal-bearing strata. In: Sedimentology of Coal and Coalbearing Sequences (Eds R.A. Rahmani and R.M. Flores), Int. Assoc. Sedimentol. Spec. Publ., 7, 13-42.

McCabe, P.J. (1991) Geology of coal; environments of deposition. In: The Geology of North America, P-2 Economic Geology, U. S (Eds H.J. Gluskoter, D.D. Rice and R.B. Taylor), pp. 469-482. The Geological Society of America, Boulder, Colorado.

McCarthy, T.S., McIver, J.R., Cairncross, B., Ellery, W.N. and Ellery, K. (1989) The inorganic chemistry of peat from the Maunachira channel-swamp system, Okavango Delta, Botswana. Geochim. Cosmochim. Acta, 53, 1077-1089.

Menning, M., Alekseev, A.S., Chuvashov, B.I., Davydov, V.I., Devuyst, F.X., Forke, H.C., Grunt, T.A., Hance, L., Heckel, P.H., Izokh, N.G., Jin, Y.G., Jones, P.J., Kotlyar, G.V., Kozur, H.W., Nemyrovska, T.I., Schneider, J.W., Wang, X.D., Weddige, K., Weyer, D. and Work, D.M. (2006) Global time scale and regional stratigraphic reference scales of Central and West Europe, East Europe, Tethys, South China, and North America as used in the Devonian-CarboniferousPermian Correlation Chart 2003 (DCP 2003). Palaeogeogr. Palaeoclimatol. Palaeoecol., 240, 318-372.

Mitchum, R.M.J. and Van Wagoner, J.C. (1991) Highfrequency sequences and their stacking patterns: sequencestratigraphic evidence of high-frequency eustatic cycles. Sed. Geol., 70, 131-147, 153-160. 
Moore, P.D. (1989) The ecology of peat-forming processes: a review. Int. J. Coal Geol., 12, 89-103.

Moore, P.D. (1995) Biological processes controlling the development of modern peat-forming ecosystems. Int. J. Coal Geol., 28, 99-110.

Moore, T.A., Shearer, J.C. and Miller, S.L. (1996) Fungal origin of oxidised plant material in the Palangkaraya peat deposit, Kalimantan Tengah, Indonesia: implications for 'inertinite' formation in coal. Int. J. Coal Geol., 30, 1-23.

Neuzil, S.G., Supardi Cecil, C.B., Kane, J.S. and Soedjono, K. (1993) Inorganic geochemistry of domed peat in Indonesia and its implication for the origin of mineral matter in coal. In: Geol. Soc. Am. Spec. Pap. (Eds J.C. Cobb and C.B. Cecil), 286, pp. 23-44.

Outerbridge, W.F. (2003) Isopach map and regional correlations of the Fire Clay tostein, Central Appalachian Basin. US Geol. Surv., Open-File Report, 03-351, 21 pp.

Page, S.E., Wüst, R.A.J., Weiss, D., Rieley, J.O., Shotyk, W. and Limin, S.H. (2004) A record of Late Pleistocene and Holocene carbon accumulation and climate change from an equatorial peat bog (Kalimantan, Indonesia): implications for past, present and future carbon dynamics. J. Quatern. Sci., 19, 625-635.

Petersen, H.I. and Andsbjerg, J. (1996) Organic facies development within Middle Jurassic coal seams, Danish Central Graben, and evidence for relative sea-level control on peat accumulation in a coastal plain environment. Sed. Geol., 106, 259-277.

Petersen, H.I., Bojesen-Koefoed, J.A., Nytoft, H.P., Surlyk, F., Therkelsen, J. and Vosgerau, H. (1998) Relative sea-level changes recorded by paralic liptinite-enriched coal facies cycles, Middle Jurassic Muslingebjerg Formation, Hochstetter Forland, Northeast Greenland. Int. J. Coal Geol., 36, $1-30$.

Polak, W. (1975) Character and occurrence of peat deposits in the Malaysian tropics. In: Modern Quaternary Research in Southeast Asia (Eds G. Bartstra and W. Casparie), pp. 77-81. Balkema, Rotterdam.

Prokopovich, N.P. (1985) Subsidence of peat in California and Florida. Bull. Assoc. Eng. Geol., 22, 395-420.

Quinlan, G.M. and Beaumont, C. (1984) Appalachian thrusting, lithospheric flexure, and the Paleozoic stratigraphy of the eastern interior of North-America. Can. J. Earth Sci., 21, 973-996.

Rice, C.L. and Hiett, J.K. 1994. Revised correlation chart of coal beds, coal zones, and key stratigraphic units in the Pennsylvanian rocks of eastern Kentucky. U.S. Geol. Surv. Misc. Field Studies Map MF-2275, 1 sheet

Rice, C.L., Belkin, H.E., Henry, T.W., Zartman, R.E. and Kunk, M.J. (1994) The Pennsylvanian Fireclay tonstein of the Appalachian Basin - its distribution, biostratigraphy and mineralogy. In: Elements of Pennsylvanian Stratigraphy, Central Appalachian Basin (Ed. C.L. Rice), Geol. Soc. Am. Spec. Pap., 294, 87-113.

Riley, N.J. and Turner, N. (1995) The Correlation of midWestphalian marine bands between the central Appalachian Basin (USA) and the United Kingdom. In: The XIII International Congress on the Carboniferous and Permian (Eds. M. Podemski, S. Dybova-Jachowicz, K. Jaworowski, J. Jureczka and R. Wagner), Polish Geological Institute, Krakow, Poland, 122 pp.

Ryer, T.A. and Langer, A.W. (1980) Thickness change involved in the peat-to-coal transformation for a bituminous coal of Cretaceous age in central Utah. J. Sed. Res., 50, 987992.
Rygel, M.C., Fielding, C.R., Frank, T.D. and Birgenheier, L.P. (2008) The magnitude of late Paleozoic glacioeustatic fluctuations: a synthesis. J. Sed. Res., 78, 500-511.

Scotese, C.R. and McKerrow, W.S. (1990) Revised world maps and introduction. In: Palaeozoic Palaeogeography and Biogeography (Eds W.S. McKerrow and C.R. Scotese), Geol. Soc. London Mem., 12, 1-21.

Scott, A.C. (1989) Observations on the nature and origin of fusain. Int. J. Coal Geol., 12, 443-475.

Scott, A.C. (2000) The Pre-Quaternary history of fire. Palaeogeogr. Palaeoclimatol. Palaeoecol., 164, 281-329.

Scott, A.C. and Jones, T.P. (1994) The nature and influence of fire in Carboniferous ecosystems. Palaeogeogr. Palaeoclimatol. Palaeoecol., 106, 91-112.

Shanley, K.W. and McCabe, P.J. (1994) Perspectives on the sequence stratigraphy of continental strata. AAPG Bull., 78, 544-568.

Shearer, J.C., Staub, J.R. and Moore, T.A. (1994) The conundrum of coal bed thickness: a theory for stacked mire sequences. J. Geol., 102, 611-617.

Silva, M.B., Kalkreuth, W. and Holz, M. (2008) Coal petrology of coal seams from the Leao-Butia Coalfield, Lower Permian of the Parana Basin, Brazil - implications for coal facies interpretations. Int. J. Coal Geol., 73, 331-358.

Spears, D.A. (1987) Mineral matter in coals, with special reference to the Pennine coal fields. In: Coal and CoalBearing Strata: Recent Advances (Ed. A.C. Scott), Geol. Soc. London Spec. Publ., 32, 171-185.

Staub, J.R. (1991) Comparisons of central Appalachian Carboniferous coal beds by benches and a raised Holocene peat deposit. Int. J. Coal Geol., 18, 45-69.

Staub, J.R. (2002) Marine flooding events and coal bed sequence architecture in southern West Virginia. Int. J. Coal Geol., 49, 123-145.

Staub, J.R. and Esterle, J.S. (1994) Peat-accumulating depositional systems of Sarawak, East Malaysia. Sed. Geol., 89, 91106.

Stopes, M.C. (1935) On the petrology of banded bituminous coals. Fuel, 14, 4-13.

Tankard, A.J. (1986) Depositional response to foreland deformation in the Carboniferous of eastern Kentucky. AAPG Bull., 70, 853-868.

Teichmüller, M. (1950) Zum petrographischen Aufbau und Werdegang der Weichbraunkohle (mit Berücksichtigung genetischer Fragen der Steinkohlenpetrographie). Geol. Jb., 64, 429-488.

Tewalt, S.J., Ruppert, L.F., Bragg, L.J., Weisenfluh, G.A., Thacker, E.E., Sites, R.S., Blake, B.M. Jr, Freeman, P.A., Bryant, L.C. and Butler, D.T. 2001. Chapter F-A digital resource model of the Middle Pennsylvanian Fire Clay coal zone, Pottsville Group, central Appalachian Basin coal region. US Geol. Surv. Prof. Pap. 1625-C.

Tornqvist, T.E. (1993) Holocene alternation of meandering and anastomosing fluvial systems in the Rhine-Meuse Delta (central Netherlands) controlled by sea-level rise and subsoil erodibility. J. Sed. Res., 63, 683-693.

Van Wagoner, J.C., Posamentier, H.W., Mitchum, R.M., Vail, P.R., Sarg, J.F., Loutit, T.S. and Hardenbol, J. (1988) An overview of the fundamentals of sequence stratigraphy and key definitions. In: Sea-Level Changes: An Integrated Approach (Eds C.K. Wiglus, B.S. Hastings, K.C.G.S.C. Kendall, H.W. Posamentier, C.A. Ross and J.C. Van Wagoner), SEPM Spec. Publ., 42, 39-45.

Veevers, J.J. (1990) Tectonic-climatic supercycle in the billionyear plate tectonic eon: Permian Pangean icehouse alter- 
nates with Cretaceous dispersed-continents greenhouse. Sed. Geol., 68, 1-16.

Wadsworth, J., Boyd, R., Diessel, C., Leckie, D. and Zaitlin, B.A. (2002) Stratigraphic style of coal and non-marine strata in a tectonically influenced intermediate accommodation setting: the Mannville Group of the Western Canadian Sedimentary Basin, south-central Alberta. Bull. Can. Petrol. Geol., 50, 507-541.

Wadsworth, J., Boyd, R., Diessel, C. and Leckie, D. (2003) Stratigraphic style of coal and non-marine strata in a high accommodation setting: Fahler and Gates Formation (Lower Cretaceous), western Canada. Bull. Can. Petrol. Geol., 51, 275-303.

Ward, C.R. and Swaine, D.J. (1995) Minerals and inorganic constituents. In: Geology of Australian Coal Basins (Eds C.R. Ward, H.J. Harrington, C.W. Mallett and J.W. Beeston), 1, pp. 93-109. Special Publication, Geological Society of Australia Coal Geology Group, Sydney.

Warwick, P.D. (2005) Coal systems analysis: a new approach to the understanding of coal formation, coal quality and environmental considerations, and as coal as a source rock for hydrocarbons. In: Coal Systems Analysis (Ed. P.D. Warwick), Goel. Soc. Am. Spec. Pap., 387, 1-8.
White, J.C., Gibling, M.R. and Kalkreuth, W.D. (1994) The Backpit seam, Sydney Mines Formation, Nova Scotia: a record of peat accumulation and drowning in a Westphalian coastal mire. Palaeogeogr. Palaeoclimatol. Palaeoecol., 106, 223-239.

Winston, R.B. (1994) Models of the geomorphology, hydrology, and development of domed peat bodies. Geol. Soc. Am. Bull., 106, 1594-1604.

Wüst, R.A.J. and Bustin, R.M. (2004) Late Pleistocene and Holocene development of the interior peat-accumulating basin of tropical Tasek Bera, Peninsular Malaysia. Palaeogeogr. Palaeoclimatol. Palaeoecol., 211, 241-270.

Wüst, R.A.J., Jacobsen, G.E., van der Gaast, H. and Smith, A.M. (2008) Comparison of radiocarbon ages from different organic fractions in tropical peat cores: insights from Kalimantan, Indonesia. Radiocarbon, 50, 359-372.

Manuscript received 7 August 2009; revision accepted 3 September 2010 